\title{
Delayed neuronal death after brain trauma involves p53-dependent inhibition of NF- $\kappa$ B transcriptional activity
}

\author{
N Plesnila ${ }^{1,5}$, L von Baumgarten ${ }^{1,5}$, M Retiounskaia ${ }^{2}$, D Engel ${ }^{1,4}$, A Ardeshiri ${ }^{1}$, R Zimmermann ${ }^{1}$, F Hoffmann ${ }^{3}$, S Landshamer ${ }^{2}$, \\ E Wagner ${ }^{2}$ and C Culmsee ${ }^{\star, 2}$
}

Acute and chronic neurodegeneration, for example, following brain injury or Alzheimer's disease, is characterized by programmed death of neuronal cells. The present study addresses the role and interaction of $p 53$ - and NF- $\kappa$ B-dependent mechanisms in delayed neurodegeneration following traumatic brain injury (TBI). After experimental TBI in mice p53 rapidly accumulated in the injured brain tissue and translocated to the nucleus of damaged neurons, whereas NF- $\kappa$ B transcriptional activity simultaneously declined. Post-traumatic neurodegeneration correlated with the increase in p53 levels and was significantly reduced by the selective p53 inhibitor pifithrin- $\alpha$ (PFT). Strikingly, this protective effect was observed even when PFT treatment was delayed up to $6 \mathrm{~h}$ after trauma. Inhibition of p53 activity resulted in the concomitant increase in NF- $\kappa \mathrm{B}$ transcriptional activity and upregulation of NF- $\kappa \mathrm{B}$-target proteins, for example X-chromosomal-linked inhibitor of apoptosis (XIAP). It is interesting to note that inhibition of XIAP abolished the neuroprotective effects of PFT in cultured neurons exposed to camptothecin, glutamate, or oxygen glucose deprivation. In conclusion, delayed neuronal cell death after brain trauma is mediated by p53-dependent mechanisms that involve inhibition of NF- $\kappa$ B transcriptional activity. Hence, p53 inhibition provides a promising approach for the treatment of acute brain injury, since it blocks apoptotic pathways and concomitantly triggers survival signaling with a therapeutic window relevant for clinical applications.

Cell Death and Differentiation (2007) 14, 1529-1541; doi:10.1038/sj.cdd.4402159; published online 27 April 2007

Traumatic brain injury (TBI) is the most common cause of death among children and young adults. The outcome in patients surviving the primary insult is mainly determined by secondary events, for example development of brain edema or delayed degeneration of axons and neurons. Experimental studies suggest that secondary events cause delayed brain damage, which finally accounts for up to $40 \%$ of the total tissue loss following brain trauma. ${ }^{1,2}$ Therapeutic options to stop this process are not available yet because the underlying molecular mechanisms are poorly understood. Accumulating evidence, however, suggests apoptotic mechanisms in delayed tissue loss after TBI, such as DNA fragmentation and regulation of pro-apoptotic proteins. ${ }^{1}$

Important regulatory steps in apoptosis occur upstream of mitochondria where members of the $\mathrm{Bcl}-2$ protein family either promote (Bax, Bid) or prevent (Bcl-2, Bcl-xl) the mitochondrial release of cytochrome $\mathrm{C}$ or apoptosis inducing factor which mediate caspase-dependent or caspase-independent cell death, respectively. ${ }^{3,4}$ A potential candidate molecule responsible for the initiation of delayed cell death in neurons upstream of mitochondria is the tumor suppressor and transcription factor $\mathrm{p} 53 .^{5}$ Previous reports demonstrated a substantial role for p53 in neuronal cell death induced by oxidative stress, DNA damaging agents, or excitotoxicity in vitro, ${ }^{6,7}$ and in experimental models of stroke in vivo. ${ }^{8,9}$ TBI also resulted in p53 upregulation ${ }^{10}$; however, so far it remained unclear whether p53 is just a bystander in the cell death process or if it plays a causal role for post-traumatic brain damage. The first aim of the present study was therefore to analyze the causal role of p53 for secondary brain damage following TBI.

In addition to transactivation of pro-apoptotic genes, for example Bax, p53 may regulate delayed neuronal death through interaction with proteins involved in the regulation of survival signaling, for example nuclear factor kappa B $(\mathrm{NF}-\kappa \mathrm{B}){ }^{5}$ This hypothesis is supported by results showing that inhibition of NF- $\kappa$ B transcriptional activity contributes to p53-dependent apoptosis, ${ }^{11}$ and by our own observations that p53 inhibited NF- $\kappa$ B in apoptotic neurons. ${ }^{12}$ It has not been addressed, however, whether such imbalance between p53 and $\mathrm{NF}-\kappa \mathrm{B}$ signaling occurs after $\mathrm{TBI}$ or contributes to the associated delayed loss of brain tissue. Among the potential $\mathrm{NF}-\kappa \mathrm{B}$ targets that exert neuroprotection, the X-chromosomelinked inhibitor of apoptosis (XIAP) is of particular interest, since recent evidence suggests a major role for XIAP in neuronal survival after lethal stress including, for example,

\footnotetext{
${ }^{1}$ Department of Neurosurgery, Institute for Surgical Research, University of Munich Medical Center - Großhadern, Munich, Germany; ${ }^{2}$ Pharmaceutical Biotechnology, Department of Pharmacy, Ludwig-Maximilians-University, Munich, Germany; ${ }^{3}$ Pharmaceutical Biology, Department of Pharmacy, Ludwig-Maximilians-University, Munich, Germany and ${ }^{4}$ Departments of Neuroscience and Neurosurgery, Erasmus MC, Rotterdam, The Netherlands

${ }^{*}$ Corresponding author: C Culmsee, Pharmazeutische Biologie - Biotechnologie, Department Pharmazie, Ludwig-Maximilians-Universität, Butenandtstraße 5-13, Gebäude D, München D-81377, Germany. Tel: + 49 (0)89 2180 77456; Fax: + 49 (0)89 2180 77791; E-mail: carsten.culmsee@ @up.uni-muenchen.de

${ }^{5}$ These authors have contributed equally to this work.

Keywords: programmed cell death; apoptosis; pifithrin; XIAP; Bax; DNA damage

Abbreviations: NF- $\kappa$ B, nuclear factor kappa B; PFT, pifithrin- $\alpha$; TBI, traumatic brain injury; XIAP, X-chromosomal-linked inhibitor of apoptosis

Received 20.9.06; revised 13.3.07; accepted 30.3.07; Edited by L Greene; published online 27.4.07
} 
cerebral ischemia ${ }^{13}$ or neonatal hypoxia. ${ }^{14}$ Accordingly, the second aim of the current study addressed the potential p53-mediated inhibition of NF- $\kappa \mathrm{B}$ after TBI and the related regulation of the neuroprotective $N F-\kappa B$ gene-target XIAP.

\section{Results}

Regulation of p53 protein correlates with secondary lesion expansion after brain trauma. The initial lesion volume measured $15 \mathrm{~min}$ after trauma $\left(18-20 \mathrm{~mm}^{3}\right)$ expanded within $24 \mathrm{~h}$ after TBI by up to $63 \%$ compared to the initial contusion volume as demonstrated in Figure 1a. Concomitantly, p53 protein levels increased in the injured cortical tissue compared to sham-operated controls as early as $15 \mathrm{~min}$ after controlled cortical impact (CCl) (Figure 1b). Quantification of p53 expression in this brain area $(n=3$
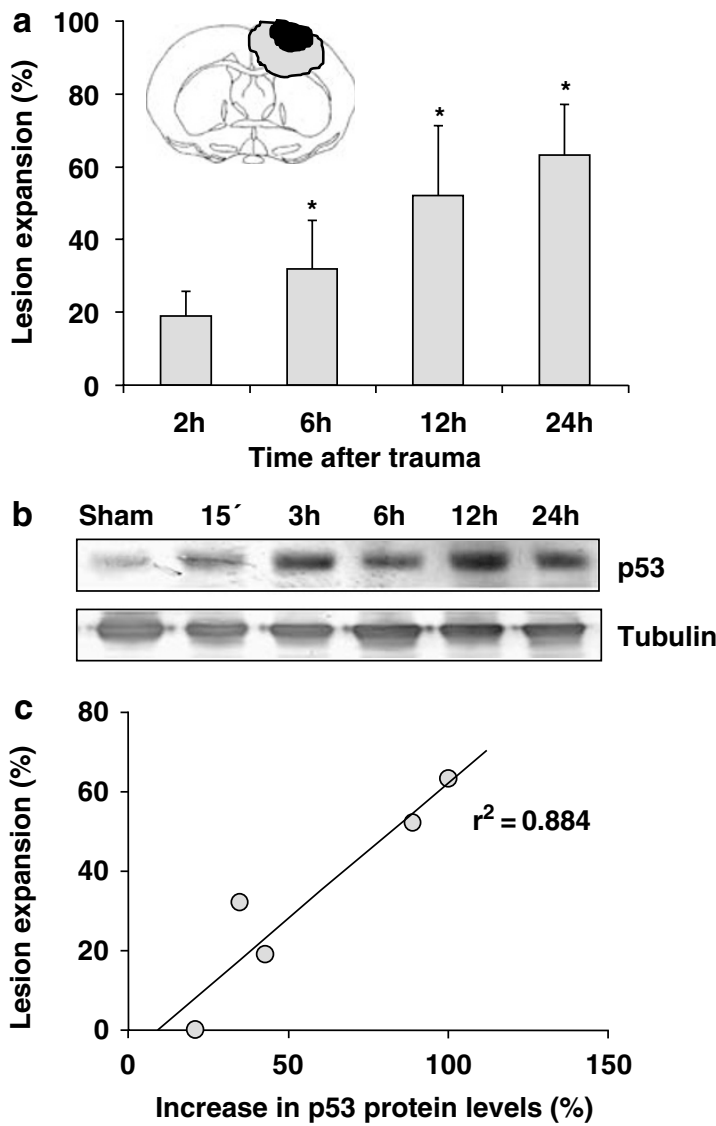

Figure 1 Temporal profile of secondary lesion expansion and p53 accumulation in contused cortex after TBI. (a) $\mathrm{C} 57 \mathrm{Bl} / 6$ mice were exposed to $\mathrm{CCl}$ and the volume of injured brain tissue was determined $2 \mathrm{~h}$ and up to $24 \mathrm{~h}$ after trauma. Contusion volume is presented as mean value and S.D. of $n=5$ animals at each time point. The numbers in the bars are the mean percentages of the increase in contusion volume compared to the initial lesion at $15 \mathrm{~min}(100 \%)$. ${ }^{*} P<0.05$ compared to $15 \mathrm{~min}$ (ANOVA, Student-Newman-Keuls). (b) Representative Western blot analysis of $\mathrm{p} 53$ protein levels. Tissue extracts were extracted from contused brain. Animals were scarified at different time points after trauma ( $15 \mathrm{~min}, 3,6,12$ and $24 \mathrm{~h} ; n=3$ per time point). (c) Correlation between lesion expansion and increase in p53 protein levels after brain trauma. Note, that p53 protein accumulation precedes secondary brain damage. Correlation coefficient $r^{2}=0.884$ animals per time point) confirmed a significant $(P<0.05$ versus sham) upregulation of p53 within $15 \mathrm{~min}$ after $\mathrm{CCl}$, which further increased 3, 6 and $12 \mathrm{~h}$ and sustained at least up to $24 \mathrm{~h}$ after trauma. The rapid increase in p53 protein levels preceded post-traumatic cell death and correlated well with the resulting expansion of the contusion volume (Figure $\left.1 \mathrm{c} ; r^{2}=0.884, P<0.05\right)$. In all tissue extracts from the other brain regions, protein levels of p53 were not different to those from sham-operated animals (data not shown).

Immunohistochemical staining confirmed that p53 immunoreactivity was enhanced in and around the contusion $6 \mathrm{~h}$ after TBI (Figures 2 and 3). Figure 2a shows enhanced p53 immunoreactivity within the area of the impact and in tissue adjacent to the contusion, which represents the site of delayed neuronal cell death. Further magnification reveals that p53 levels were increased in contused brain tissue (Figure 2b); however, p53 levels were also elevated in still viable neurons in the vicinity of the contusion but not in the non-injured contralateral hemisphere (Figure $2 c$ and d). These cells die in the process of secondary brain damage within the first $24 \mathrm{~h}$ after trauma, suggesting that p53 is involved in the observed delayed brain damage.

Nuclear counterstaining of p53-stained brain sections with the DNA-binding fluorescent dye DAPI revealed greatly enhanced p53 immunoreactivity in still viable neurons located in the vicinity of the contusion (Figure $3 a$ and $b$ ). According to the assumed function of p53 as a pro-apoptotic transcription factor, p53 immunoreactivity was located to the nucleus in damaged neurons (Figure $3 \mathrm{c}$ and $\mathrm{d}$ ). By contrast, weak cytosolic p53 staining was detected in normal neurons in the contralateral hemisphere (Figure $3 e$ and f). Double immunostaining with an anti-p53 antibody and an anti-NeuN antibody confirmed that increases in p53 levels and nuclear translocation occurred in neurons in the damaged brain tissue (core and penumbra) (Figure 4a).

Inhibition of p53 reduces delayed tissue loss after brain trauma. To further elucidate a causal role for p53 for delayed tissue loss after trauma, the effect of pharmacological p53 inhibition by pifithrin- $\alpha$ (PFT) was studied. PFT prevented the increase in p53 levels and nuclear translocation in the cortical tissue (Figure 4a) and in the hippocampus (Supplementary Figure 1) adjacent to the primary insult when applied immediately before the TBI. Similar to our previous findings in vitro, ${ }^{7}$ the $\mathrm{p} 53$ inhibitor PFT also blocked p53 transcriptional activity in brain tissue after systemic application as demonstrated by reduced protein levels of Bax (Figure $4 b$ and $c$ ). The therapeutic effect of the p53 inhibitor PFT after TBI was first assessed in a dose finding study, where PFT was administered $1 \mathrm{~h}$ before trauma. Comparison of contusion volumes in control animals $15 \mathrm{~min}$ and $24 \mathrm{~h}$ after trauma confirmed that delayed cell death results in additional tissue loss $(+63 \%$ as compared to the damage measured immediately after trauma). Maximal post-traumatic contusion volumes in PFTtreated animals were significantly smaller as compared to vehicle-treated controls. Delayed lesion growth was reduced by 6 and $8 \mathrm{mg} / \mathrm{kg}$ PFT in a dose-dependent manner by 29 and $43 \%$, respectively, as compared to vehicle-treated 

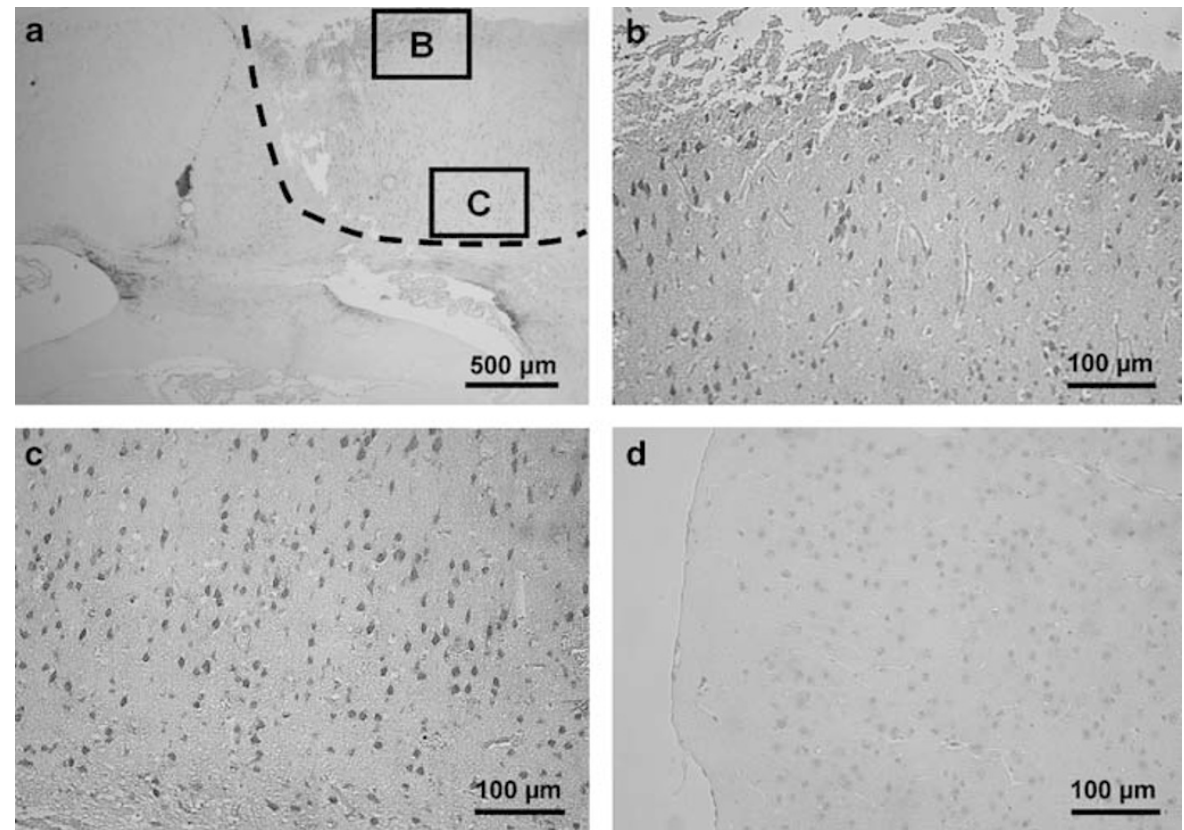

Figure 2 Immunohistochemistry of p53 after TBI. (a) Increased p53 expression (dark red color) $6 \mathrm{~h}$ after TBI in vital and contused mouse brain (indicated by dotted line). (b) High magnification of the cells located in the traumatic contusion. p53 is increased and located to the nucleus. (c) Also the pericontusional area, where cells are still viable $6 \mathrm{~h}$ after trauma, but will undergo delayed cell death within the next 6-12 h, contain neurons with pronounced p53 immunoreactivity. (d) The contralateral cortex (control) shows normal, that is low, expression of p53 in normal brain

controls ( $P<0.05, n=10$ per group). Next, the therapeutic window of PFT was assessed in a study where treatment was initiated after trauma. In this series of experiments, a single dose of $8 \mathrm{mg} / \mathrm{kg}$ PFT was applied $15 \mathrm{~min}, 1,3$ or $6 \mathrm{~h}$ after trauma (Figure 5a). Post-treatment with PFT at this dose reduced delayed lesion expansion by more than $50 \%$ as compared to vehicle-treated controls $(P<0.05, n=7$ per group). Notably, this strong cerebroprotective effect was obtained even when PFT was applied $6 \mathrm{~h}$ after trauma. To fully elucidate the therapeutic window of PFT, a second posttreatment experiment was performed including an application of PFT 6 and $12 \mathrm{~h}$ after trauma. In this experiment, protection by PFT applied $6 \mathrm{~h}$ after trauma was well reproduced, whereas PFT administration $12 \mathrm{~h}$ after trauma did not alter delayed lesion expansion (Figure $5 b$ ). To evaluate whether PFT only delayed the infarct development by slowing down apoptotic mechanisms, additional experiments were performed where the infarct volume was determined 7 days after trauma. The results presented in Figure $5 \mathrm{c}$ show that the protective effect of the p53 inhibitor was sustained when PFT was administered $3 \mathrm{~h}$ after ischemia. In contrast, the protective effect was not detectable anymore at 7 days after trauma when PFT was administered $6 \mathrm{~h}$ after the insult (Figure 5c).

Although a sustained protection of brain tissue was not detectable after 7 days in the group treated with a single dose of PFT $6 \mathrm{~h}$ after the injury, these animals still showed significantly improved performance in a beam-walking paradigm, indicating persistently improved motor function by the p53 inhibitor (Figure 5d). In addition, animals treated with PFT $6 \mathrm{~h}$ after brain injury performed as well as non-traumatized animals in the Object Recognition Test (ORT). The ORT evaluates short-term memory, an ability often impaired in brain trauma patients. Animals treated with vehicle were not able to differentiate new objects (Figure 5e). Of note, PFT $(8 \mathrm{mg} / \mathrm{kg})$ did not affect blood pressure or blood gases (Table 1). These data demonstrate significant and persistent cerebroprotective effects and functional improvement by the p53 inhibitor with a therapeutic time window relevant for clinical applications.

Inhibition of NF- $\kappa \mathrm{B}$ transcriptional activity and reduced XIAP protein levels after TBI. NF- $\kappa$ B DNA binding and NF$\kappa \mathrm{B}$ transcriptional activity were determined in protein extracts from different brain areas at various time points from $3 \mathrm{~h}$ and up to $24 \mathrm{~h}$ after TBI. In samples containing the contusion (quadrant $\mathrm{c}$ ), NF- $\kappa \mathrm{B}$ DNA binding was not altered within $6 \mathrm{~h}$ after trauma and increased significantly within $24 \mathrm{~h}$ (Figure $6 \mathrm{a}$ and $\mathrm{b}$ ), whereas the transcriptional activity was significantly reduced at 3,6 and $24 \mathrm{~h}$ after $\mathrm{CCl}$ as compared to control levels (Figure $6 \mathrm{c}$ ). In line with the findings on NF- $\kappa \mathrm{B}$ transcriptional inhibition levels of the $\mathrm{NF}-\kappa \mathrm{B}$ transcription target XIAP were persistently reduced in traumatized brain tissue up to $45 \%$ of control levels within 12-24h (Figure $6 \mathrm{~d}$ and e). It is interesting to note that after trauma cleavage, products of XIAP were detected in injured tissue indicating functional loss of the protein (Figure $6 \mathrm{~d}$ ). In contrast to the site of injury, NF- $\kappa \mathrm{B}$ DNA binding and NF- $\kappa \mathrm{B}$ transcriptional activity were enhanced in non-injured brain tissue of the ipsilateral hemisphere (quadrant d, Supplementary Figure 2). In the contralateral hemisphere, neither NF- $\kappa$ B DNA binding nor NF- $\kappa$ B transcriptional activity were affected after brain trauma (quadrant a, Supplementary Figure 3). 

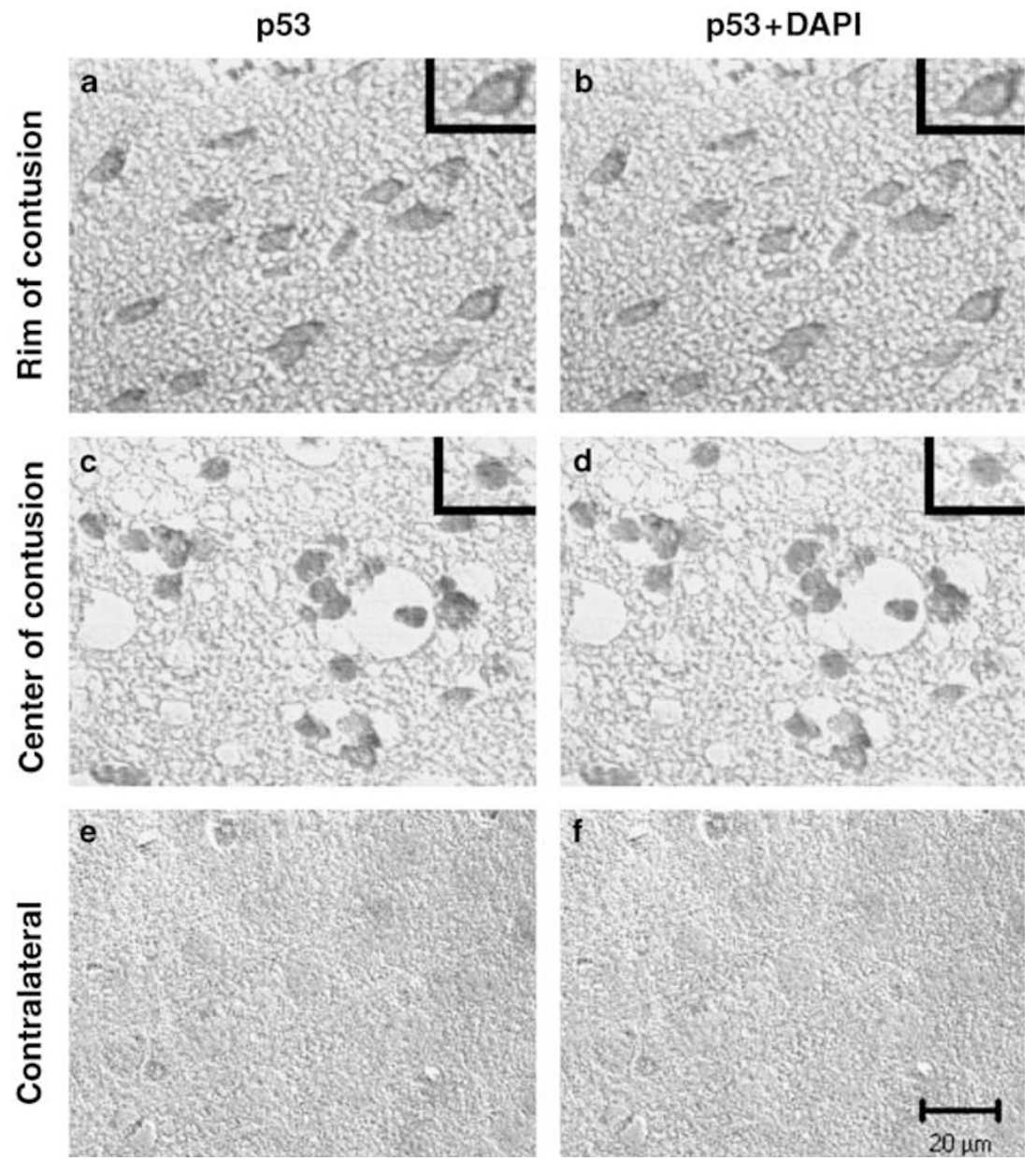

Figure 3 Enhanced nuclear and cytosolic levels of p53 at $6 \mathrm{~h}$ after TBI. Immunohistochemical staining of p53 (left panels) and co-staining with the nuclear dye DAPI (right panels) reveal enhanced neuronal cytosolic and nuclear p53 levels $6 \mathrm{~h}$ after brain trauma (a and $\mathbf{b}$ ), and predominantly nuclear localization of p53 in neurons within the (necrotic) contusion area (c and $\mathbf{d})$. (e and $\mathbf{f}$ ) Contralateral hemisphere

The p53 inhibitor PFT enhances NF- $\kappa$ B transcriptional activity and XIAP protein levels after $\mathbf{C C I}$. In brains of naïve animals, PFT reduced protein levels of the p53-target protein Bax (Figure 4) and concomitantly enhanced NF- $\kappa \mathrm{B}$ transcriptional activity (Figure 7a) and expression levels of the NF- $\kappa$ B transcriptional-target XIAP (Figure $7 b$ ). Analyses of brain tissue from traumatized $\mathrm{NF}-\kappa \mathrm{B}$ luciferase reporter mice revealed that PFT preserved NF- $\kappa \mathrm{B}$ activity in damaged brain tissue (quadrant $\mathrm{c}$ ) and significantly enhanced NF- $\kappa \mathrm{B}$ transcriptional activity in non-injured brain (quadrant $d$, Figure $7 c$ and d). Similar effects were found in the contralateral hemisphere (quadrant a, Supplementary Figure 3), where PFT significantly enhanced NF- $\kappa \mathrm{B}$ transcriptional activity in a similar extent as in the noninjured ipsilateral tissue adjacent to the trauma site (Figure 7d). Co-immunohistochemistry revealed that PFT induced $\mathrm{NF}-\kappa \mathrm{B}$ translocation to the nucleus predominantly in neurons (Figure 8). Such $\mathrm{NF}-\kappa \mathrm{B}$ translocation was significantly enhanced in neurons in tissue adjacent to the injury site (Figure 8) as well as in cortical tissue in the contralateral hemisphere. Most strikingly, PFT significantly enhanced protein levels of XIAP in injured brain tissue after TBI (quadrant c, Figure 9) as well as in non-injured ipsilateral brain tissue in sham-operated animals and in animals after TBI (quadrant d, data not shown). This increase in XIAP levels occurred predominantly in neurons as shown by co-immunohistochemistry (Figure 9a). Overall, these data clearly demonstrated that the protective effect of the p53 inhibitor PFT was accompanied by increased NF- $\kappa$ B activity and enhanced expression of the NF- $\kappa \mathrm{B}$ transcriptional-target XIAP in neurons.

Involvement of XIAP in PFT-mediated neuroprotection. Similar to the findings in vivo, p53 inhibition enhanced neuronal expression of XIAP in cultured neurons and XIAP levels were reduced by $56.4 \pm 6.2 \% \quad(P<0.001)$ compared to controls after DNA damage and induction of p53-dependent apoptosis by camptothecin (Figure 10a), whereas the p53 inhibitor PFT enhanced XIAP expression levels in vitro (Figure 10b). To evaluate whether enhanced XIAP levels are indeed involved in neuroprotection by PFT the XIAP inhibitor 
a
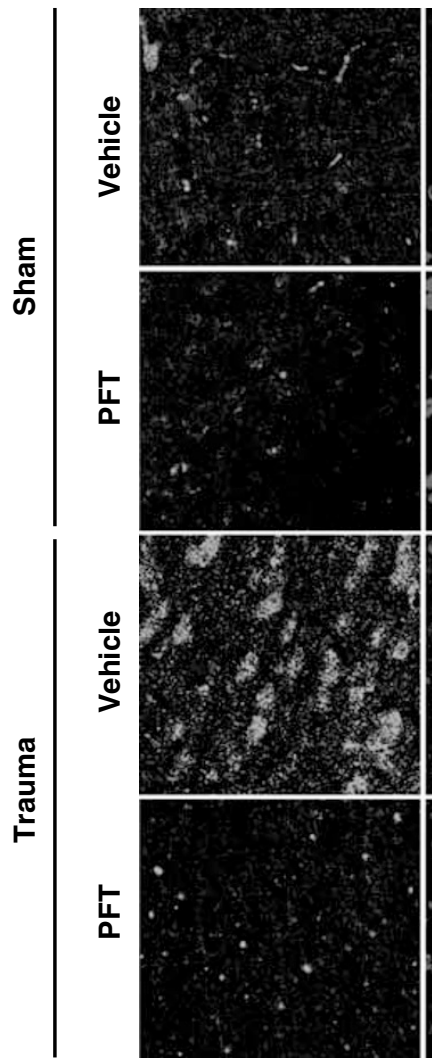

b

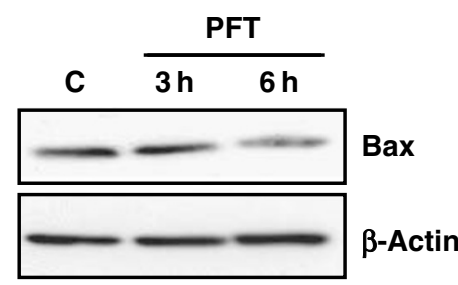

NeuN
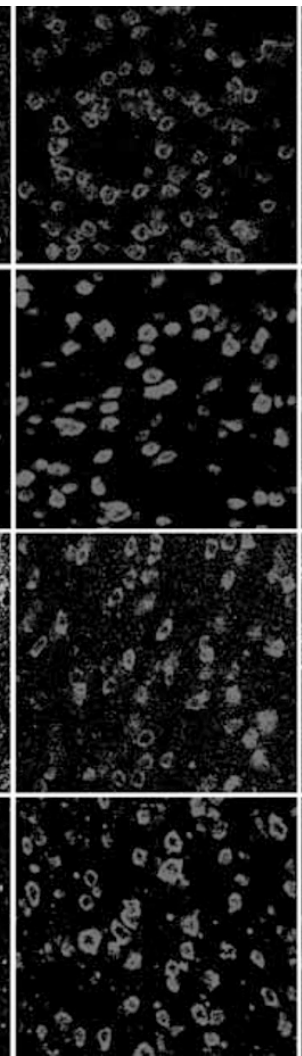

p53/NeuN
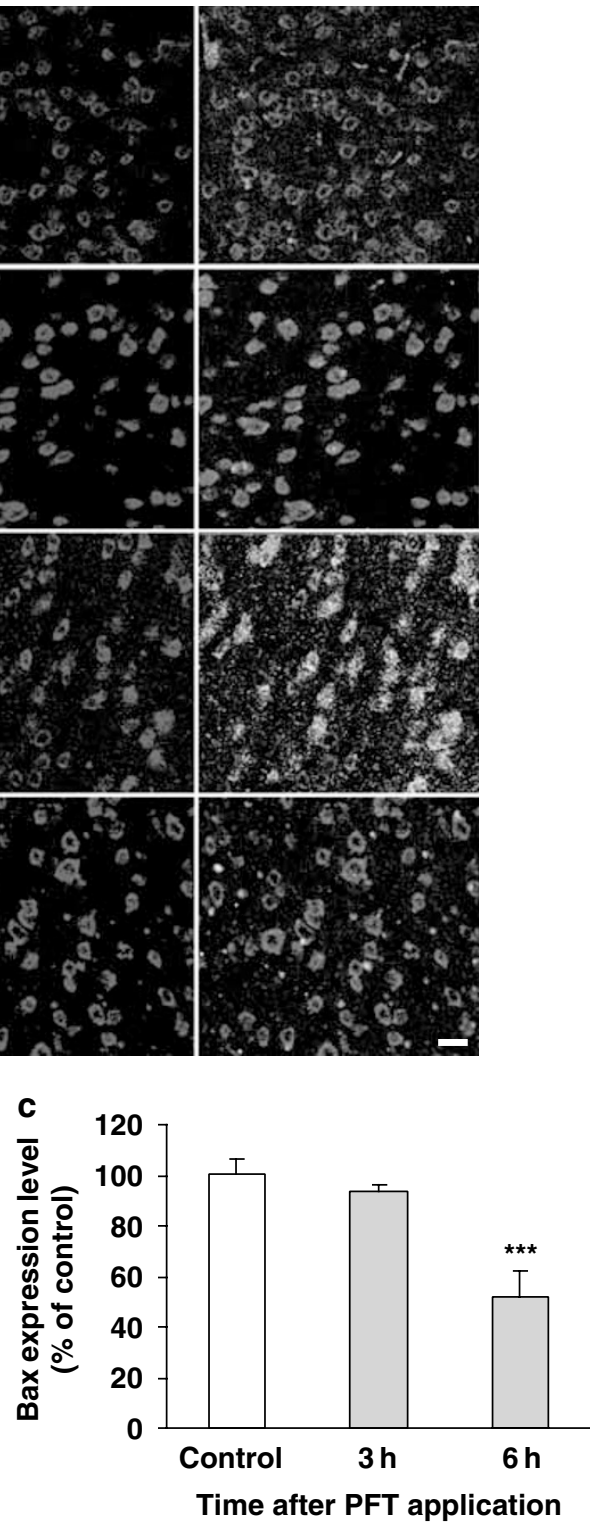

Figure 4 The p53 inhibitor PFT prevents p53 accumulation and reduces Bax expression in cortical brain tissue. (a) Co-immunohistochemistry of p53 and NeuN in cortical brain tissue. The upper panels show immunostainings of cortical tissue of sham-operated mice treated with vehicle or the p53 inhibitor PFT for $6 \mathrm{~h}$. The lower panels show tissue from mice $6 \mathrm{~h}$ after trauma. The mice were treated with vehicle or PFT immediately before trauma. The stainings confirm low p53 immunoreactivity in sham-operated animals, while p53 clearly accumulates in neurons in the cortical penumbra adjacent to the contusion area. PFT prevented the increase in p53 levels and nuclear translocation in the neurons of the penumbra region. The overlays with NeuN immunostaining (red) reveals that the vast majority of the cells with increased p53 levels in the cortical penumbra are neurons. (b) Western blot analysis of protein extracts from mouse brain tissue reveals reduced levels of Bax protein $6 \mathrm{~h}$ after intraperitoneal application of PFT $(8 \mathrm{mg} / \mathrm{kg}$ ). (c) Quantification of the results partly presented in (a) from $n=4$ animals per group (ANOVA, Duncan's)

embelin was applied. Embelin reversed PFT-mediated neuroprotection in three different in vitro models of neuronal cell death induced by camptothecin, glutamate or oxygen-glucose deprivation (OGD) (Figure 10c, Supplement Figure 4). suggesting that p53 indeed promotes cell death not only by enhancing expression of proapoptotic proteins like Bax, but also by inhibition of survival pathways mediated by $\mathrm{NF}-\kappa \mathrm{B}$ and its downstreamtarget XIAP.

\section{Discussion}

The present data demonstrate a major role for $\mathrm{p} 53$ in delayed neuronal cell death after TBI. p53 protein levels rapidly increased in the injured brain hemisphere within the first $12 \mathrm{~h}$ after experimental brain trauma and remained elevated up to $24 \mathrm{~h}$ after injury. p53 accumulation correlated well with delayed brain damage tissue following TBI and the p53 inhibitor PFT significantly attenuated this process. Most 


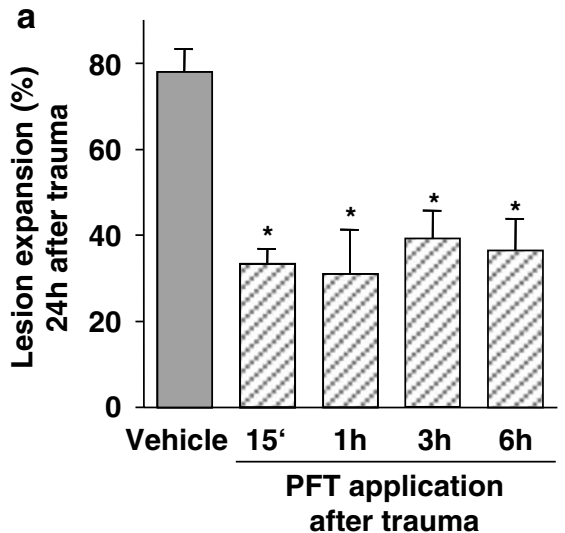
after trauma

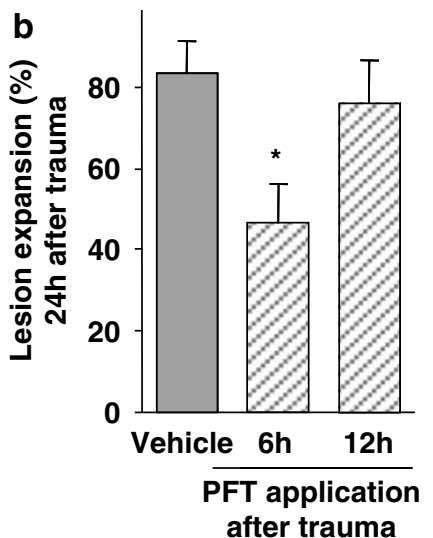

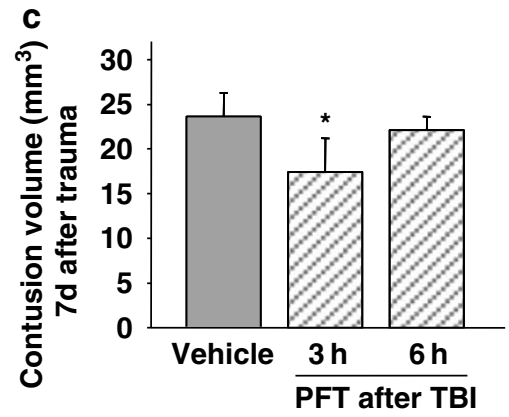
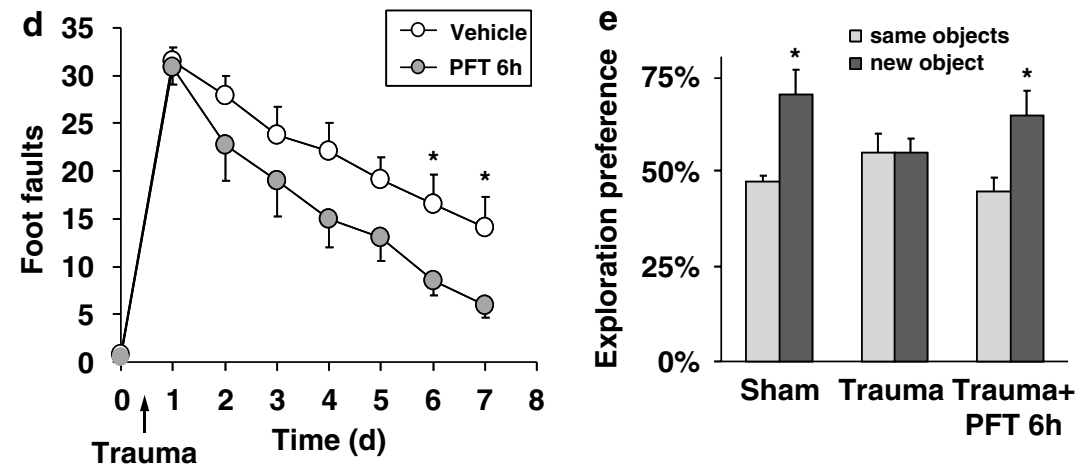

Figure 5 Effect of PFT treatment on contusion volume and functional outcome. (a and $\mathbf{b}$ ) Effect of PFT post-treatment on contusion volume $24 \mathrm{~h}$ after CCl. Contusion volume of PFT-treated and respective vehicle-treated control animals $24 \mathrm{~h}$ after CCI. PFT (8 mg/kg) was given intraperitoneally $15 \mathrm{~min}$, and up to $12 \mathrm{~h}$ after trauma. In a first series of experiments, PFT reduced the secondary lesion expansion by approximately $50 \%$ when administered up to $6 \mathrm{~h}$ after $\mathrm{CCl}$ (a). A second post-treatment experiment confirmed a therapeutic window for the cerebroprotective effect of PFT up to $6 \mathrm{~h}$ after $\mathrm{CCl}$, whereas application of PFT $12 \mathrm{~h}$ after injury showed no effect (b). (c) In an additional experiment, PFT was applied 3 or $6 \mathrm{~h}$ after trauma and the brains were removed for measurements of the infarct size 7 days later. Sustained protection of brain tissue was only detected in animals receiving PFT $3 \mathrm{~h}$ after the injury, whereas $6 \mathrm{~h}$ after treatment did not result in reduced contusion volumes compared to vehicle controls at 7 days after trauma. (d and e) PFT treatment $6 \mathrm{~h}$ after brain trauma significantly improved motor and memory function as demonstrated by significantly less foot faults in a beam-walking paradigm $(n=10)(\mathbf{d})$ and restored exploratory preference of a newly presented object in the ORT (e), respectively. Mean and S.E.M. from $n=7-11$ animals; ${ }^{*} P<0.05$ versus vehicle-treated controls; ANOVA on ranks, Student-Newman-Keuls

Table 1 Mean arterial blood pressure before and after $8 \mathrm{mg} / \mathrm{kg}$ pifithrin- $\alpha$ (PFT)

\begin{tabular}{lcl}
\hline & PFT (8 $\mathbf{~ m g / k g )}$ & Vehicle \\
\hline 15 min before & $68 \pm 5$ & $67 \pm 22$ \\
Injection & $64 \pm 7$ & $68 \pm 9$ \\
15 min after & $68 \pm 5$ & $61 \pm 7$ \\
35 min after & $66 \pm 10$ & $62 \pm 7$
\end{tabular}

Injection of PFT i.p. had no effect on mean arterial blood pressure (mm Hg; mean + S.D.; $n=5$ per group) of mice. intriguingly, this cerebroprotective effect measured at $24 \mathrm{~h}$ after injury was still achieved when a single dose of PFT was applied up to $6 \mathrm{~h}$ after TBI. Protection of brain tissue was still detectable 7 days after trauma when PFT was administered $3 \mathrm{~h}$ after ischemia. PFT administered $6 \mathrm{~h}$ after TBI did not lead to a sustained protection of brain tissue, but significantly improved functional recovery. Following brain injury, functional improvements may occur without significant reduction of contusion or infarct volume. ${ }^{15}$ Overall, our findings indicate that the p53 inhibitor preserved brain tissue and enhanced 
a
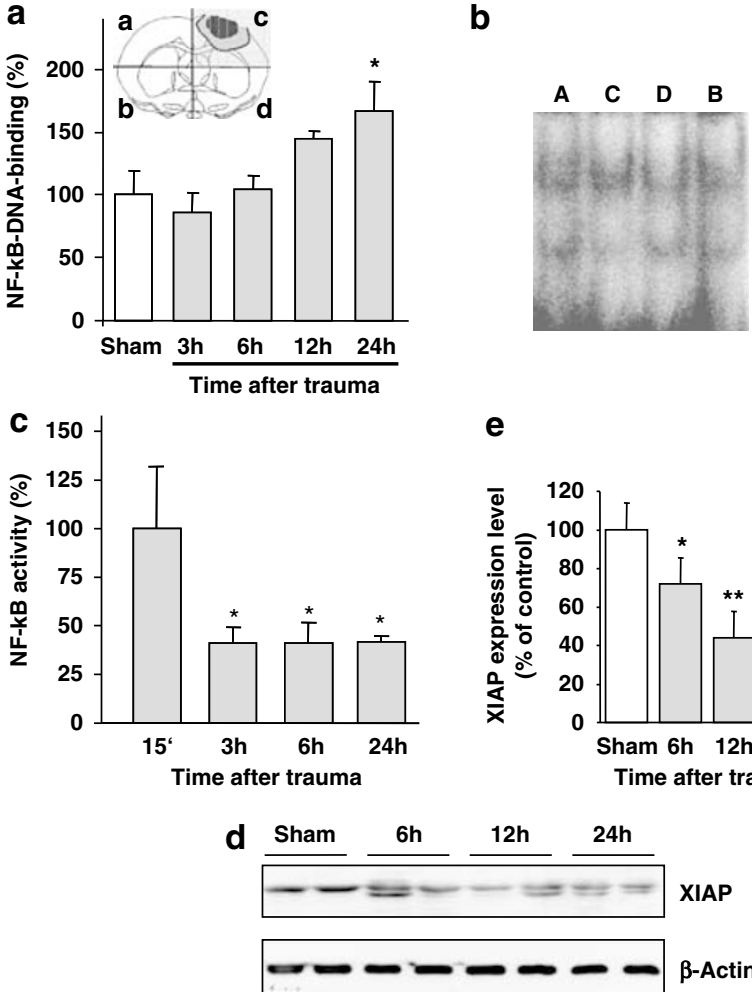

Figure 6 NF- $\kappa$ B transcriptional activity is reduced in injured brain tissue after $\mathrm{CCl}$. NF- $\kappa \mathrm{B}$ DNA binding (a and $\mathbf{b})$ and NF- $\kappa \mathrm{B}$ transcriptional activity (c) was determined in protein extracts from the injured brain region of NF- $\kappa B$ luciferase reporter mice $15 \mathrm{~min}$ and up to $24 \mathrm{~h}$ after $\mathrm{CCl}$. Note that the NF- $\kappa B$ p65 DNAbinding ELISA (a) reveals no increase in the NF- $\kappa B$ DNA-binding activity in area $\mathrm{C}$ within $6 \mathrm{~h}$ after trauma similar to the electromobility shift assay with nuclear protein extracts from this tissue region after $6 \mathrm{~h}(\mathbf{b})$. This indicates that the decrease in NF- $\kappa \mathrm{B}$ transcriptional activity quantified in NF- $\kappa \mathrm{B}$ luciferase reporter mice (c) was not due to increased binding of inhibitory NF- $\kappa$ B p50: p50 dimers. In (a and $\mathbf{c}$ ) mean values and S.D. are presented from three animals. ${ }^{*} P<0.05$ compared to controls (ANOVA, Duncan's). (d) Western blot analysis revealed reduced XIAP protein levels at $6 \mathrm{~h}$ and up to $24 \mathrm{~h}$ after brain trauma compared to sham-operated animals. Analysis of two out of four animals per group are shown. $\beta$-Actin was detected as a loading control. (e) Quantification of the upper (non-cleaved) XIAP signal from the immunoblot results partly presented in (d) from $n=4$ animals per group (ANOVA, Duncan's)

functional regeneration with a wide therapeutic time window after TBI.

It is noteworthy that inhibition of p53 transcriptional activity is a major mechanism by which PFT prevents the pro-apoptotic action of the tumor suppressor protein. Here, we demonstrated that p53 inhibition reduced the expression of the pro-apoptotic protein Bax in mouse brain, a finding which is in line with our previous findings in cultured neurons. ${ }^{7}$ The underlying mechanism may involve inhibition of p53 accumulation, inhibition of nuclear translocation or interference with the p53 transcriptional machinery by PFT. For example, we show here that PFT blocked the increase in p53 levels and nuclear translocation in neurons when PFT was applied immediately before the traumatic injury. However, inhibition of p53-dependent apoptosis by PFT does not necessarily require inhibition of p53 accumulation. ${ }^{7,16}$ In particular, when applied 3 or $6 \mathrm{~h}$ after trauma when p53 levels are already increased, PFT likely exerts neuropro-

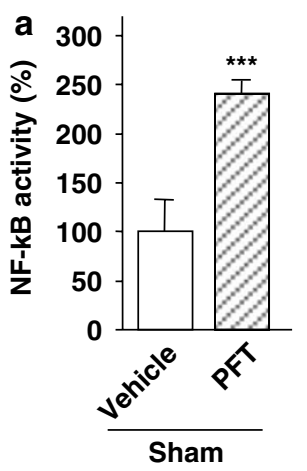

b

C

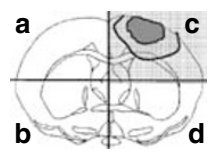

d
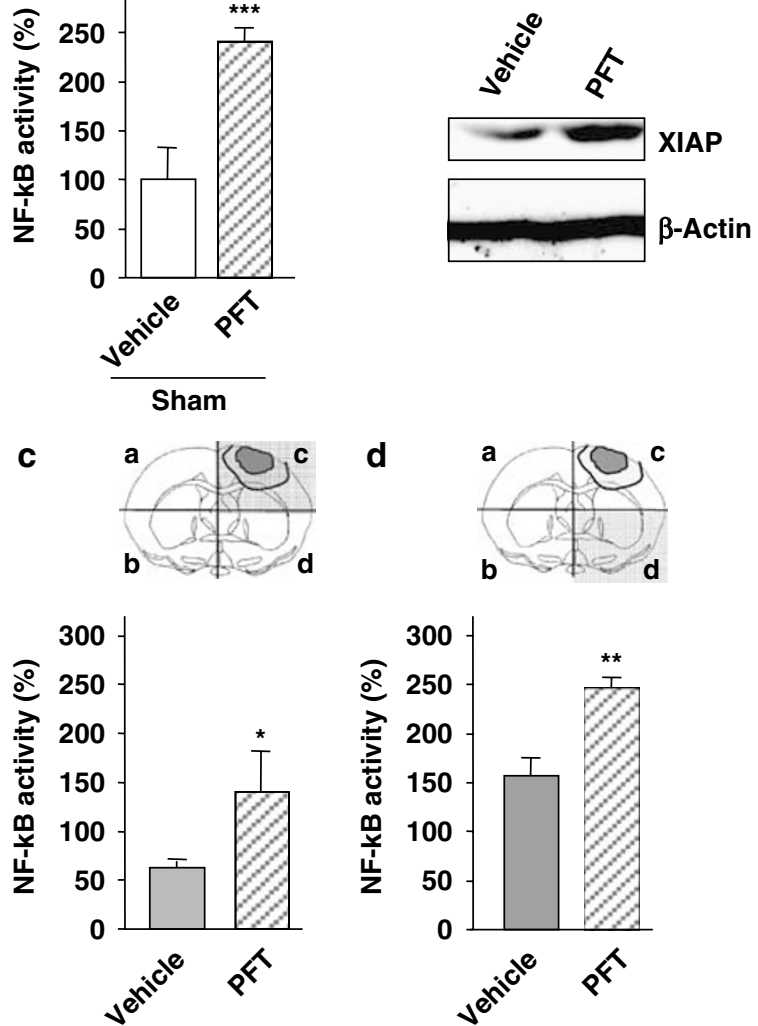

Figure 7 Inhibition of $p 53$ enhances NF- $\kappa$ B activity and XIAP protein expression levels in mouse brain tissue. (a) PFT enhanced NF- $\kappa$ B transcriptional activity within $6 \mathrm{~h}$ after systemic application in brain tissue of sham-operated NF- $\kappa \mathrm{B}$ luciferase reporter mice. (b) Western blot analysis of protein extracts from mouse brain tissue reveals that PFT enhances expression of XIAP in naïve mouse brain. After brain trauma, inhibition of p53 by PFT also enhances NF- $\kappa$ B transcriptional activity in the contused tissue area (quadrant c) (c) and in adjacent non-injured brain tissue (quadrant d) (d). Mean values and S.D. from three animals are presented. ${ }^{\star} P<0.05,{ }^{* \star} P<0.01$ and ${ }^{\star \star \star} P<0.001$ compared to the respective vehicle-treated controls (ANOVA, Duncan's)

tection by blocking further nuclear translocation and by interfering with $\mathrm{p} 53$ transcriptional activity.

In neurons, the tumor suppressor and transcription factor p53 is activated and contributes to cell death after exposure to various forms of apoptotic stress, including glutamateinduced excitotoxicity, DNA damage, hypoxia or oxidative stress. ${ }^{5}$ A key role of p53 for neuronal cell death is further supported by studies on the pathology of neurodegenerative diseases, for example Parkinson's disease, Alzheimer's disease or amyotrophic lateral sclerosis, where increased p53 levels were detected in degenerating neurons. ${ }^{17}$ In addition, previous studies exposed p53-dependent neuronal death in experimental models of epileptic seizures and cerebral ischemia. $7,12,18$

The pro-apoptotic functions of p53 are largely promoted through transactivation of specific target genes such as Bax, PUMA or Noxa. ${ }^{5}$ In addition, p53 may mediate cell death through mechanisms independent of transcriptional activity, for example through interference with endogenous 
a
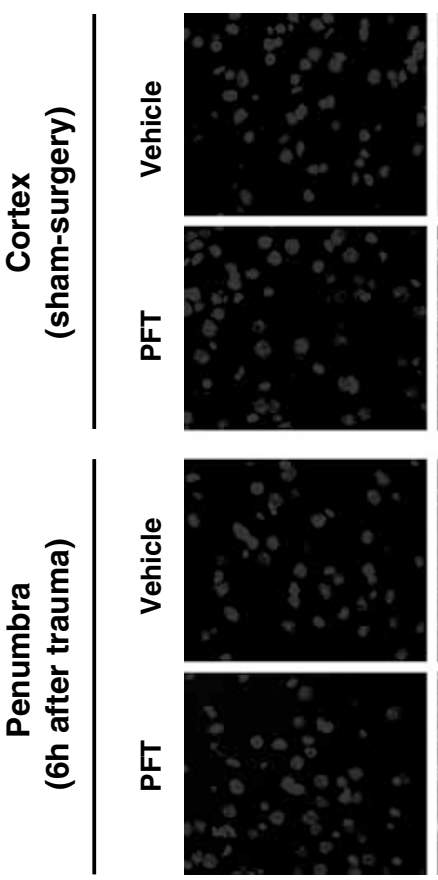

b

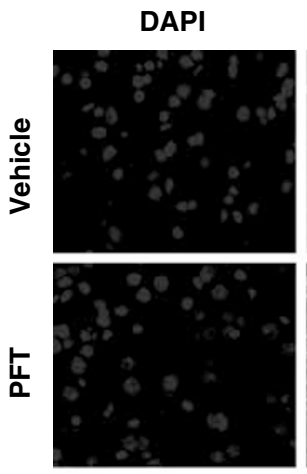
NF-kB/p65
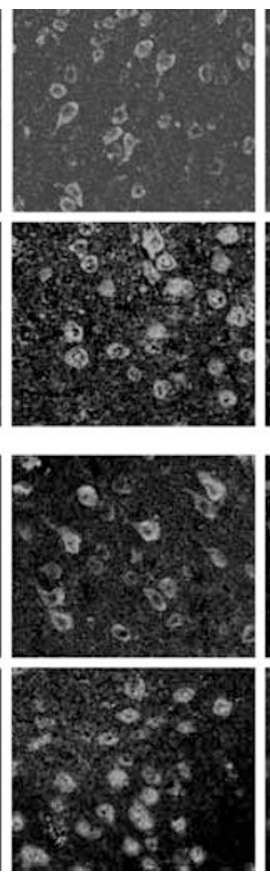

NeuN
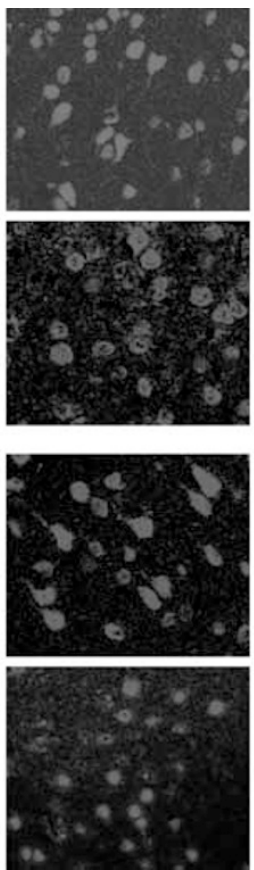

merge
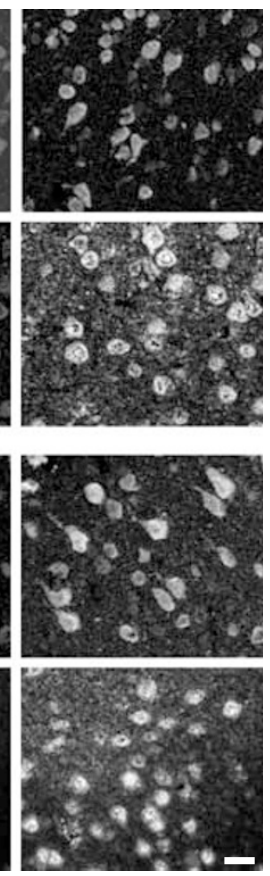

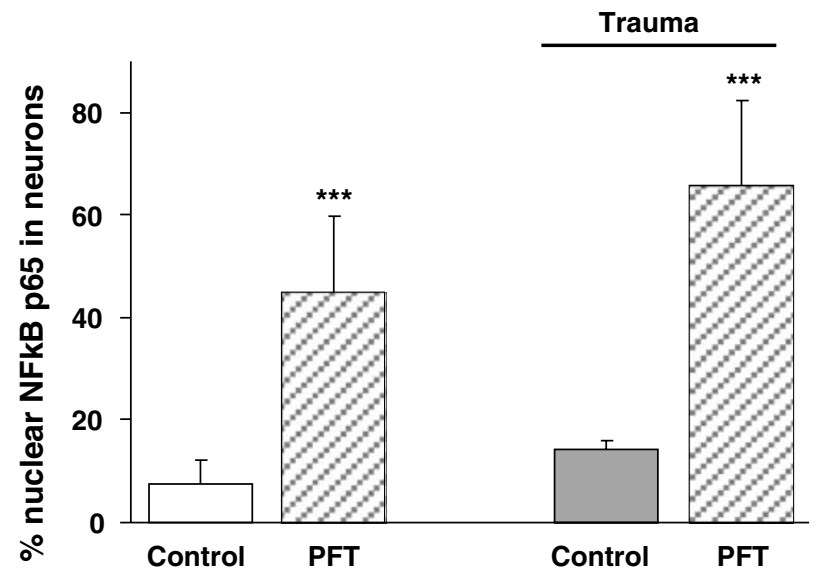

Figure 8 Increased nuclear translocation of NF- $\kappa$ B p65 after treatment with the p53 inhibitor occurs in neurons. (a) Co-immunohistochemistry of NF- $\kappa$ B p65 and NeuN in cortical brain tissue. The upper panels show immunostainings of cortical tissue of sham-operated mice treated with the p53 inhibitor PFT $6 \mathrm{~h}$ before removing the brains. The lower panels show tissue from mice $6 \mathrm{~h}$ after trauma and PFT treatment. In line with NF- $\kappa \mathrm{B}$ activity measurements, NF- $\kappa \mathrm{B}$ p65 (green) translocation to the nuclei (blue) occurs in sham-operated and PFT-treated animals. Further, slightly increased NF- $\kappa$ B p65 staining is observed in the penumbra of the contusion $6 \mathrm{~h}$ after trauma, and this nuclear translocation is significantly enhanced in PFT-treated mice. The overlay with NeuN immunostaining (red) reveals that the vast majority of the cells with NF- $k B$ p65 nuclear translocation are neurons. (b) Quantification of the results on NF- $\kappa$ B p65 nuclear translocation in neurons $6 \mathrm{~h}$ after PFT treatment in sham-operated animals and after traumatic injury in the tissue adjacent to the contusion (ANOVA, Duncan's)

survival mechanisms after translocation of $\mathrm{p53}$ to the mitochondria ${ }^{19-21}$ or by transcriptional repression due to interactions with the transcriptional cofactors CBP/p300. ${ }^{11,12}$ Here, we found that delayed brain damage and accumulation of p53 protein after trauma were accompanied by inhibition of NF- $\kappa \mathrm{B}$ transcriptional activity in injured brain tissue. The p53 inhibitor PFT enhanced NF- $\kappa$ B activity in injured brain and in adjacent ipsilateral cortex and this effect clearly correlated with enhanced neuronal survival and rescue of brain tissue. The current results obtained in vivo are supported by our previous observations in cultured neurons where p53 inhibition enhanced $\mathrm{NF}-\kappa \mathrm{B}$ activity thereby mediating neuroprotection. ${ }^{7,12}$ The neuroprotective potential of $\mathrm{NF}-\kappa \mathrm{B}$ is also supported by the observation that increased NF- $\kappa \mathrm{B}$ activity was detected in brain tissue adjacent to the lesion site that survived the insult without morphological signs of damage. These results imply that increased $\mathrm{NF}-\kappa \mathrm{B}$ activity is associated with neuronal survival, whereas reduced $\mathrm{NF}-\kappa \mathrm{B}$ transcriptional activity is rather associated with neuronal cell death after acute brain injury. This conclusion is also supported by the pivotal role of constitutive NF- $\kappa \mathrm{B}$ transcriptional activity for neuronal 
a
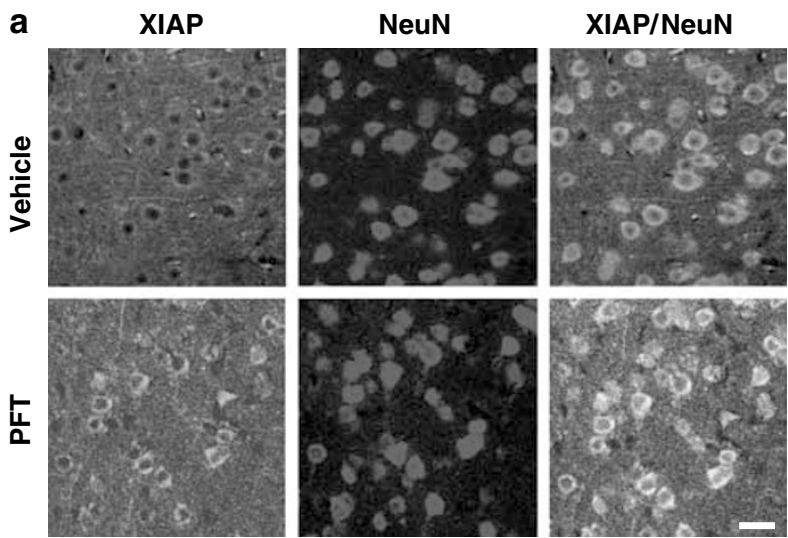

b

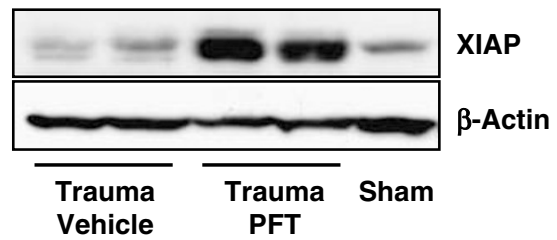

C

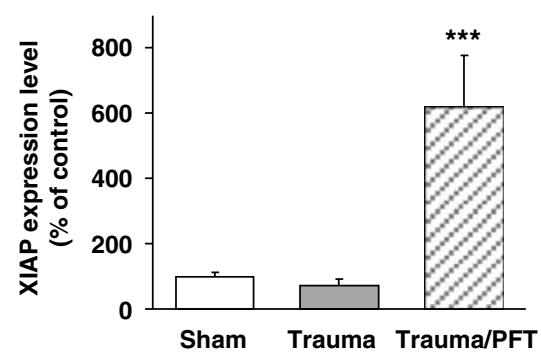

Figure 9 Neuronal expression of XIAP increases in PFT-treated animals. (a) Co-immunohistochemistry of XIAP (green) and NeuN (red) in cortical brain tissue adjacent to the injury $6 \mathrm{~h}$ after $\mathrm{CCl}$. The upper panels show immunostainings of cortical tissue from vehicle-treated mice, the lower panels show tissue from animals treated with the p53 inhibitor PFT. Note that in PFT-treated animals, the immunoreactivity against XIAP increased in neurons. (b) Western blot analysis shows enhanced expression levels of XIAP protein $6 \mathrm{~h}$ after PFT application compared to vehicle-treated controls in the contused tissue area. $\beta$-Actin was detected as a loading control. (c) Quantification of the XIAP signal from the immunoblot results partly presented in (b) from $n=4$ animals per group (ANOVA, Duncan's)

survival and plasticity during embryogenesis and in adulthood. ${ }^{22,23}$

It is noteworthy that in contrast to the reduced NF- $\kappa \mathrm{B}$ transcriptional activity, the NF- $\kappa \mathrm{B}$ DNA binding activity was not blocked but even increased in injured brain within $24 \mathrm{~h}$ after TBI. This is in line with many reports indicating enhanced $\mathrm{NF}-\kappa \mathrm{B}$ nuclear translocation and DNA binding activity in brain tissue after cerebral ischemia ${ }^{24}$ or brain trauma. ${ }^{25}$ Since these findings strongly suggested that neuronal death after acute brain injury was associated with enhanced NF- $\kappa$ B activation, a role for $\mathrm{NF}-\kappa \mathrm{B}$ in neuronal cell death was postulated. ${ }^{26,27} \mathrm{We}$ now demonstrate that an increase in NF- $\kappa$ B p65 DNA binding activity does not necessarily correlate with NF- $\kappa \mathrm{B}$ transcriptional activity. In our model of TBI, NF- $\kappa$ B DNA binding increased within $24 \mathrm{~h}$, whereas the NF- $\kappa$ B transcriptional activity rapidly declined within $3 \mathrm{~h}$ and was still reduced $24 \mathrm{~h}$ a

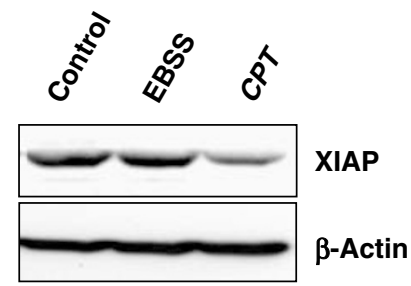

b

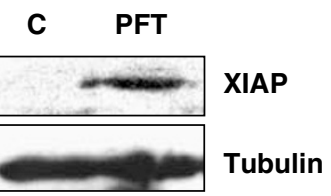

C
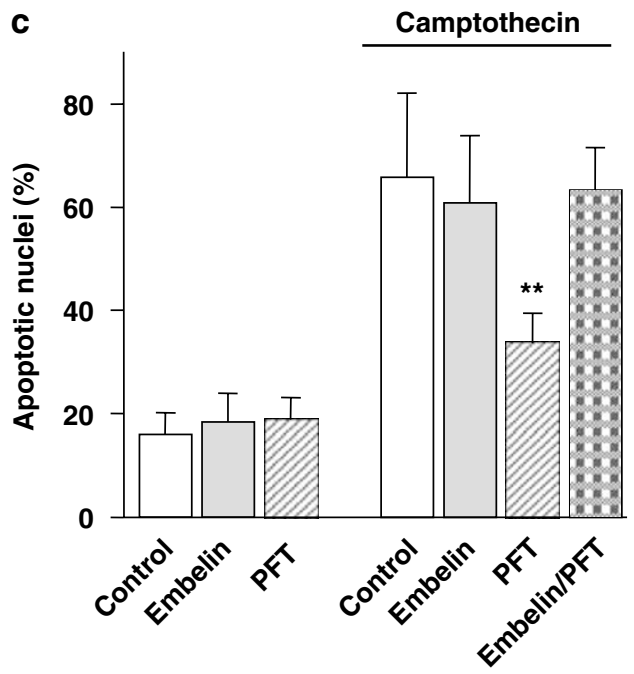

Figure 10 Involvement of XIAP in protective effects of PFT in cultured embryonic rat neurons. (a and $\mathbf{b}$ ) In cultured rat embryonic neurons, protein expression levels of the NF- $\kappa$ B-regulated protein XIAP decreased after exposure to camptothecin (CPT, $10 \mu \mathrm{M})$, whereas the p53 inhibitor PFT $(200 \mathrm{nM})$ increased protein levels of XIAP in this culture system. $\beta$-Actin immunostaining served as loading control. (c) The XIAP inhibitor embelin was added to rat neuronal cultures $2 \mathrm{~h}$ and the p53 inhibitor PFT $(200 \mathrm{nM}) 1 \mathrm{~h}$ before induction of cell death by CPT $(10 \mu \mathrm{M})$. The percentage of apoptotic nuclei was determined $24 \mathrm{~h}$ later after nuclear staining with DAPI. Mean values and S.D. of percentage of apoptotic nuclei from five dishes per group are presented. ${ }^{* *} P<0.01$ compared to CPT-treated cells (ANOVA, Scheffé's)

after the insult. These data underline the importance to measure NF- $\kappa \mathrm{B}$ transcriptional activity, while detection of NF- $\kappa \mathrm{B}$ DNA binding may result in misleading interpretations.

Measurement of the NF- $\kappa \mathrm{B}$ reporter protein, however, clearly shows that such NF- $\kappa$ B activation and enhanced DNAbinding activity does not necessarily translate into transcriptional activity after acute brain injury but rather the opposite effect as demonstrated here, that is transcriptional repression of NF- $\kappa \mathrm{B}$ after brain trauma.

It has to be considered that inhibition of NF- $\kappa \mathrm{B}$ p65 DNA binding could result from enhanced activity of inhibitory NF- $\kappa \mathrm{B}$ p50:p50 dimers. By using an electromobility shift assay, however, we confirmed that overall NF- $\kappa$ B DNA binding was not altered within $6 \mathrm{~h}$ after trauma, suggesting that the observed rapid block of NF- $\kappa$ B transcriptional activity $3-6 \mathrm{~h}$ after trauma was not attributable to enhanced activation of 


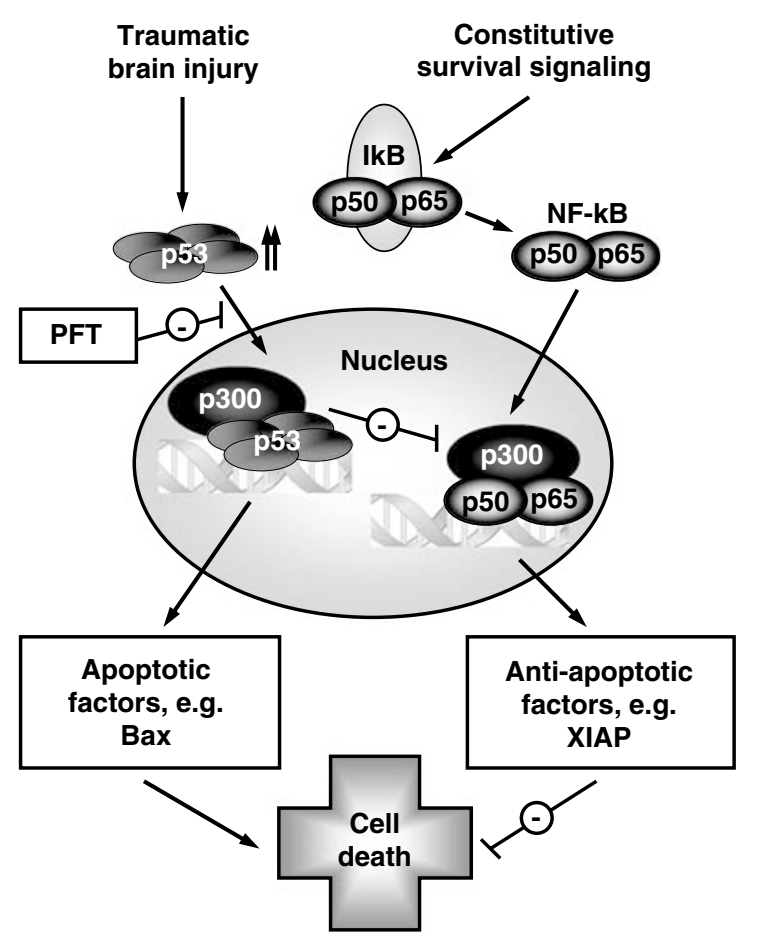

Figure 11 p53-mediated delayed neuronal death after brain trauma involves inhibition of NF- $\kappa \mathrm{B}$. After $\mathrm{TB}$, the proapoptotic transcription factor $\mathrm{p} 53$ rapidly accumulates and translocates to the nucleus of injured neurons. In the nucleus, activated p53 transactivates pro-apoptotic factors, for example Bax which execute the delayed neuronal death that causes secondary brain tissue loss after trauma. In contrast, survival signaling in neurons involves nuclear translocation of NF- $\kappa \mathrm{B}$, which can enhance synthesis of anti-apoptotic proteins, for example XIAP. Both transcription factors compete for co-transcription factors such as p300/CBP to stimulate synthesis of pro- or anti-apoptotic factors. Thus, p53 activation after brain trauma results in reduced NF- $\kappa$ B survival signaling. On the other hand, pharmacological inhibition of p53 by PFT indirectly supports NF- $\kappa$ B transcriptional activity and therefore provides an efficient neuroprotective strategy, since inhibition of the p53-dependent cell death program concomitantly stimulates NF- $\kappa \mathrm{B}$ dependent transactivation of survival factors, for example XIAP

inhibitory p50:p50 dimers. Most likely, the observed early inhibition of NF- $\kappa$ B transcriptional activity that precedes the expansion of brain damage was mediated by p53. p53 accumulated rapidly after trauma and could inhibit NF- $\kappa \mathrm{B}$ despite previous release from the $\mathrm{I} \kappa \mathrm{B}$ complex and translocation to the nucleus (Figure 10). Such inhibitory cross talk between $\mathrm{p} 53$ and NF- $\kappa \mathrm{B}$ in the nucleus has been attributed to competitive binding to transcriptional cofactors, such as p300, which may either bind $\mathrm{p} 53$ or NF- $\kappa \mathrm{B}$ to promote the respective transcriptional activity. ${ }^{11}$ In cultured neurons, the p53 inhibitor PFT shifted the binding of p300 toward NF- $\kappa \mathrm{B}$ thereby accelerating NF- $\kappa \mathrm{B}$ transcriptional activity and transactivation of neuroprotective factors. ${ }^{12}$ Previous reports on the protective effects of the p53 inhibitor against irradiation-induced cell death $^{16}$ and ischemic brain lesion ${ }^{18}$ suggested that PFT acts by preventing the nuclear translocation of $p 53$. Both, inhibition of p53 nuclear import and inhibition of p53 binding to p300 within the nucleus may equally contribute to the presently observed enhanced NF- $\kappa$ B activity, in particular when PFT was applied 3-6h after trauma, when p53 already accumulated in the nucleus. Further studies are required to delineate in more detail the nature of NF- $\kappa \mathrm{B}$ transcriptional activity after $\mathrm{TBI}$ regarding the involved NF- $\kappa \mathrm{B}$ subunits and potential interaction with transcriptional cofactors. In the present study, the PFT-mediated shift of transcriptional activities of p53 (blocked) and NF- $\kappa \mathrm{B}$ (enhanced) resulted in reduced protein levels of the p53-target Bax and increased expression of the $\mathrm{NF}-\kappa \mathrm{B}$-target XIAP in vitro and in vivo (Figure 11). Similar to other members of the inhibitory of apoptosis protein family, XIAP prevents cell death by various mechanisms ${ }^{28-30}$ and was attributed a critical role for neuronal cell death in various disease models, for example cerebral ischemia, ${ }^{13,31,32}$ neonatal hypoxia, ${ }^{14}$ retinal ischemia ${ }^{33}$ or epileptic seizures. ${ }^{34}$ In line with the observed reduction of NF- $\kappa \mathrm{B}$ transcriptional activity, protein levels of full-length XIAP declined after TBI in injured brain tissue. Further, we detected cleavage of XIAP after trauma, indicating loss of function of this pro-survival protein in the injured brain. The p53 inhibitor PFT counteracted this process and increased XIAP expression in contused as well as in healthy brain. Thus, PFT-mediated neuroprotection and induction of NF- $\kappa \mathrm{B}$ transcriptional activity correlated well with enhanced levels of the NF- $\kappa$ B transcriptional-target XIAP.

Further evidence for the involvement of XIAP in PFTmediated neuroprotection was obtained in cultured neurons exposed to different apoptotic insults. We found that the XIAP inhibitor embelin blocked the protective effect of PFT against neuronal apoptosis induced by camptothecin, glutamate or $\mathrm{OGD}$, thereby strongly suggesting the involvement of NF- $\kappa \mathrm{B}$ dependent regulation of XIAP in the observed neuroprotective effect. Hence, the present study adds evidence for the compelling role of XIAP in neuronal survival and in the neuroprotective effect of p53 inhibition in particular, since the XIAP inhibitor embelin abolished the neuroprotective effect of PFT in the various models of apoptosis.

In conclusion, our study demonstrates a causal role for p53 in delayed brain damage after experimental brain trauma and that the underlying p53 death signaling involves inhibition of $\mathrm{NF}-\kappa \mathrm{B}$. In contrast, neuroprotective inhibition of $\mathrm{p} 53$ results in enhanced $N F-\kappa B$ transcriptional activity and expression of protective target genes such as XIAP. Inhibition of p53 and concomitant activation of survival signaling by PFT therefore emerges as an attractive therapeutic strategy for the treatment after TBI, since our findings suggest pronounced protective effects of the p53 inhibitor with a clinically relevant therapeutic time window.

\section{Materials and Methods}

Animals. All efforts were made to minimize suffering and the number of animals according to the guidelines of the German animal protection law and derived guidelines on the ethical use of animals. Female Sprague-Dawley rats (gestation day 18) and male C57BL/6 mice were obtained from Charles River (Sulzfeld, Germany). NF- $\kappa$ B-luciferase-reporter mice (genetic background: C57BL/6) were used for the measurement of NF- $\kappa \mathrm{B}$ transcriptional activity as described previously. ${ }^{12}$ The NF- $\kappa$ B-luciferase transgene contained the firefly luciferase gene, driven by two NF- $\kappa$ B sites responding to $\mathrm{p} 65 / \mathrm{p} 50$, p50/cRel and other dimer combinations of $\mathrm{NF}-\kappa \mathrm{B}$ as established in previous studies. ${ }^{35,36}$ All animals were kept under controlled light and environmental conditions $(12 \mathrm{~h}$ dark/light cycle, $23 \pm 1{ }^{\circ} \mathrm{C}, 55 \pm 5 \%$ relative humidity) and had free access to food (Altromin, Germany) and water.

CCI in mice. Male C57/Bl6 mice (25-28 g, Charles River, Kisslegg, Germany) were anaesthetized in a halothane chamber $(4 \%)$. Anesthesia was maintained with 
a facemask using $1.2 \%$ halothane, in a mixture of $30 \% \mathrm{O}_{2}$ and $70 \% \mathrm{~N}_{2} \mathrm{O}$. Body temperature during anesthesia was kept constant at $37^{\circ} \mathrm{C}$ by a feedback-controlled heating pad. TBI was performed as described earlier. ${ }^{2}$ Briefly animals were craniotomized above the right parietal cortex under continuous cooling with saline using a high-speed drill. $\mathrm{CCl}$ was performed perpendicular to the surface of the brain (impactor tip diameter: $3 \mathrm{~mm}$, impact velocity: $8 \mathrm{~m} / \mathrm{s}$, brain compression: $1 \mathrm{~mm}$ for $150 \mathrm{~ms})$. Thereafter, the craniotomy was closed with the initially removed bone flap using conventional tissue glue (Histoacryl, Braun-Melsungen, Melsungen, Germany). The skin over the craniotomy was carefully closed and animals were transferred to an incubator heated to $35^{\circ} \mathrm{C}$ until recovery of spontaneous motor activity. Sham-operated animals underwent the same surgical procedure including anesthesia and craniotomy but did not receive impact injury.

In the first series of experiments, male C57/Bl6 mice ( $n=10$ per group, $25-28 \mathrm{~g})$ received 6 or $8 \mathrm{mg} / \mathrm{kg}$ PFT (Calbiochem, Merck Bioscience $\mathrm{GmbH}$, Schwalbach, Germany) intraperitonealy $1 \mathrm{~h}$ before trauma. Control animals received the same volume of vehicle before and after trauma $(0.6 \%$ dimethylsulfoxide/saline, $n=10$ per group). The doses of PFT were chosen on the basis of therapeutically efficacious concentrations previously used in models of middle cerebral artery occlusion in mice. ${ }^{7,12}$ Control animals were sacrificed $15 \mathrm{~min}$ and $24 \mathrm{~h}$ after trauma to obtain primary and secondary lesion volumes. All treated animals were sacrificed $24 \mathrm{~h}$ after trauma. In a second series of experiments, the therapeutic window of PFT was established. Male C57/Bl6 mice ( $n=7$ per group) received PFT in a dose of $8 \mathrm{mg} / \mathrm{kg}$ via intraperitoneal injection $15 \mathrm{~min}, 1,3,6$ or $12 \mathrm{~h}$ after $\mathrm{CCl}$. Controls received vehicle at $6 \mathrm{~h}$ after brain trauma ( $0.8 \%$ dimethylsulfoxide/saline).

For quantification of brain injury, animals were sacrificed by cervical dislocation in deep halothane anesthesia. Brains were carefully removed, frozen in dry ice and stored at $-80^{\circ} \mathrm{C}$ until further use. Histomorphometric quantification was performed as described earlier. ${ }^{2}$ Briefly, $10 \mu \mathrm{m}$ coronal sections were collected every $500 \mu \mathrm{m}$ on a cryostat (CryoStar HM 560, Microm, Walldorf, Germany) and stained with cresyl violet. The contusion area of each section was measured on digitized images with a standard image analysis software (Optimate 6.52, Media Cybernetics, Silver Spring, MD, USA) by an investigator blinded to the treatment of the animals. The infarct volume $\left(V_{i}\right)$ was calculated based on the contusion areas $(A)$ obtained from 15 sections by the equation:

$$
V_{\mathrm{i}}=0.5 \mathrm{~mm} \times\left(\mathrm{A}_{1}+\mathrm{A}_{2}+\ldots+\mathrm{A}_{15}\right)
$$

Physiological parameters. Physiological parameters were measured in male C57/BI6 mice $(n=5)$ in long-term anesthesia induced by an intraperitoneal injection of medetomidine $(0.5 \mathrm{mg} / \mathrm{kg}$, Domitor, Dr E Graeub AG, Basel, Switzerland), Fentanyl ( $0.05 \mathrm{mg} / \mathrm{kg}$ b.w., Janssen-Cilag, Neuss, Germany) and Midazolam ( $5 \mathrm{mg} / \mathrm{kg}$ b.w., Dormicum, Roche, Basel, Switzerland). Animals were intubated with an orotracheal tube and mechanically ventilated (MiniVent 845, Hugo Sachs Elektronik, March-Hungstetten, Germany) using $30 \% \mathrm{O}_{2}$. Entidal $\mathrm{CO}_{2}$ was measured continuously using microcapnography (Microcapnograph $\mathrm{Cl} 240$, Columbus instruments, Columbus, $\mathrm{OH}$, USA). Body temperature was maintained at $37.0^{\circ} \mathrm{C}$ by a feedback-controlled heating pad. A catheter was introduced into the femoral artery for continuous measurement of mean arterial blood pressure (MABP) and for blood sampling. Arterial blood gases, arterial pH, sodium and potassium concentrations were measured $30 \mathrm{~min}$ before and $30 \mathrm{~min}$ after intraperitoneal injection of PFT ( $8 \mathrm{mg} / \mathrm{kg}, n=5)$ or vehicle ( $0.8 \%$ dimethylsulfoxide/saline, $n=5)$.

Embryonic neuronal cultures. Cortices were removed from the brains of embryonic day 18 (E18) rats or embryonic day 14 (E14) mice, and cells were dissociated by mild trypsination and trituration as described previously. ${ }^{7}$ The dissociated neurons were then seeded onto polyethyleneimine-coated $35 \mathrm{~mm}$ culture dishes (for survival analysis) or $60 \mathrm{~mm}$ culture dishes (for protein analysis) and grown in Neurobasal medium (Invitrogen, Karlsruhe, Germany) supplemented with $5 \mathrm{mM}$ HEPES, $1.2 \mathrm{mM}$ glutamine, B27 supplement (Invitrogen, Karlsruhe, Germany, $20 \mathrm{ml} / \mathrm{l})$ and gentamicin $(0.1 \mathrm{mg} / \mathrm{ml})$. All experimental treatments were performed on 8- to 10-day-old cultures, at which time they contained less than $5 \%$ astrocytes as determined previously by GFAP immunocytochemistry. ${ }^{36}$ PFT was added to the cultures at a final concentration of $200 \mathrm{nM}$. Camptothecin $(10 \mu \mathrm{M}$; Sigma, Deisenhofen, Germany) were added $1 \mathrm{~h}$ after pretreatment with the p53 inhibitor. Dimethylsulfoxide (Sigma, Deisenhofen, Germany) at a final concentration of $0.1 \%$ was used as the vehicle for PFT and camptothecin. For OGD, glucose-free EBSS medium $\left(6800 \mathrm{mg} / \mathrm{l} \mathrm{NaCl}, 400 \mathrm{mg} / \mathrm{KCl}, 264 \mathrm{mg} / \mathrm{l} \mathrm{CaCl} \mathrm{Cl}_{2} \times 2 \mathrm{H}_{2} \mathrm{O}, 200 \mathrm{mg} / \mathrm{l}\right.$ $\mathrm{MgCl}_{2} \times 7 \mathrm{H}_{2} \mathrm{O}, \quad 2200 \mathrm{mg} / \mathrm{ll} \quad \mathrm{NaHCO}_{3}, \quad 140 \mathrm{mg} / \mathrm{l} \quad \mathrm{NaH}_{2} \mathrm{PO}_{4} \times \mathrm{H}_{2} \mathrm{O}, \quad$ pH 7.2 ) supplemented with gentamicin $(5 \mathrm{mg} / \mathrm{l})$ was purged with $\mathrm{N}_{2} / \mathrm{CO}_{2}(95 \% / 5 \%)$ for 30 min resulting in oxygen content of $2-3 \%$. After 10 days in culture, neurons were washed three times with this medium and incubated for $4 \mathrm{~h}$ in an oxygen-free $\mathrm{N}_{2} / \mathrm{CO}_{2}(95 \% / 5 \%)$ atmosphere. Control cultures were incubated in EBSS with $10 \mathrm{mM}$ glucose. Thereafter, the medium was replaced by standard culture medium (see above). To induce glutamate excitotoxicity, neurons (10 days in culture) were exposed to $20 \mu \mathrm{M}$ glutamate in EBSS with $10 \mathrm{mM}$ glucose. At 4, 8, 12, or $24 \mathrm{~h}$ after onset of PFT treatment or the indicated apoptotic challenges, cells were harvested for protein extraction or fixed with $4 \%$ formaldehyde in phosphate-buffered saline (PBS) quantification of cell death, respectively. Neuronal apoptosis was quantified after staining the nuclei with the DNA-binding fluorochrome Hoechst 33258 (Molecular Probes, Göttingen, Germany) according to standard protocols as described previously. ${ }^{37}$ Experiments were repeated at least twice and analyses were performed without the knowledge of the treatment history.

NF- $\kappa$ B DNA-binding activity. NF- $\kappa$ B DNA binding activity was determined in brain extracts with the TransAM NF- $\kappa B$ p65 activation assay according to the manufacturer's protocol (Active Motif, Rixensart, Belgium). Briefly, brain tissue from the different brain quadrants as outlined above were extracted with freshly prepared Complete Lysis Buffer. Samples with $10 \mu \mathrm{g}$ of protein in $20 \mu \mathrm{l}$ were added to $30 \mu \mathrm{l}$ Binding Buffer in the assay wells and incubated for $1 \mathrm{~h}$ at room temperature (RT). Later, the wells were washed three times with $200 \mu$ l Washing Buffer. The NF- $\kappa$ B antibody (1:1000 dilution in antibody binding buffer) was added and incubated for $1 \mathrm{~h}$ at RT. After further washing steps, the secondary HRP-conjugated antibody ( $1: 1000$ dilution) was added, incubated for $1 \mathrm{~h}$ at RT, washed and then the wells were incubated with developing solution $(100 \mu \mathrm{l})$ for $10 \mathrm{~min}$. Afterwards, $100 \mu \mathrm{l}$ Stop Solution was added and the absorbance was determined within $5 \mathrm{~min}$ at $450 \mathrm{~nm}$ with a reference wavelength of $655 \mathrm{~nm}$. Blank controls received Complete Lysis Buffer without protein, and positive controls were incubated with cell extracts from Jurkat cells delivered with the assay. NF- $\kappa$ B DNA binding was determined in duplicates of each sample and corrected for total protein content.

Luciferase assay. Luciferase activity was measured in protein extracts from cultured neurons or brain tissue obtained from $\mathrm{E} 14 \kappa \mathrm{B}$-luciferase reporter mice using a luciferase detection kit according to the manufacturer's protocol (Promega, Madison, WI, USA) as described previously. ${ }^{12}$ Briefly, after treatment intervals of $6-24 \mathrm{~h}$, the cells were scraped in ice-cold PBS, centrifuged at $600 \times \mathrm{g}$ for $10 \mathrm{~min}$ at $4{ }^{\circ} \mathrm{C}$, and the pellet was homogenized in $100-150 \mu$ l of luciferase reporter lysis buffer. In addition, cortical and hippocampal brain tissue from NF- $\kappa$ B-reporter mice was homogenized in $500 \mu \mathrm{l}$ reporter lysis buffer $1-24 \mathrm{~h}$ after PFT treatment and/or onset of focal cerebral ischemia. Brain and cell homogenates were centrifuged at $14000 \times g$ for $10 \mathrm{~min}$ at $4^{\circ} \mathrm{C}$, and total protein content in the supernatant was determined using the Pierce BCA kit (Perbio Science, Bonn, Germany). Aliquots of $30 \mu \mathrm{l}$ of the protein extracts were added to $100 \mu \mathrm{l}$ of luciferase assay buffer containing the luciferase assay substrate, and immediately measured in a luminometer. Luminescence was expressed in an arbitrary scale as relative light units (RLU). Because some analyses were performed in parallel with different sets of cultures and different badges of luciferin reagent, values were expressed as RLU as percentage of control values. Double measurements were performed with each sample and every experiment was repeated at least twice to confirm the results. All analyses were performed without knowledge of the treatment history.

\section{Immunoblot analysis}

Brain tissue. Male $\mathrm{C} 57 / \mathrm{Bl} 6$ mice were subjected to $\mathrm{CCl}$ and sacrificed at various time points thereafter ( $15 \mathrm{~min}, 3,6,12$, and $24 \mathrm{~h} ; n=3$ per time point). A separate group of sham-operated mice (anesthesia and craniotomy but no trauma, $n=3$ ) served as controls. Brains were carefully removed and cut into 4-mm thick coronal sections using a brain matrix. The coronal section containing the contusion was further divided into four quadrants (Figure 1a). Quadrants $a$ and $b$ contained tissue from the contralateral hemisphere. Quadrant $c$ contained the contusion, while quadrant $d$ contained the non-injured ipsilateral tissue. The quadrants were homogenized at $4^{\circ} \mathrm{C}$ in complete lysis buffer containing a protease inhibitor cocktail and DTT (Active Motif, Rixensart, Belgium), centrifuged at 13000 r.p.m. for $15 \mathrm{~min}$ and stored at $-80^{\circ} \mathrm{C}$ until further use. Protein concentration was determined using the Bradford method (Bio-Rad Laboratories, Hercules, CA, USA). ${ }^{38}$ Proteins were separated using a 10\% Bis-Tris gel (Invitrogen, Carlsbad, CA, USA; $10 \mu \mathrm{g} /$ lane) by electrophoresis and transferred into a nitrocellulose membrane. The membranes were incubated with primary antibodies for $\mathrm{p} 53$ (mouse monoclonal, Cell Signaling Technologies, Beverly, MA, USA), XIAP (rabbit polyclonal, BD Biosciences, San 
Diego, CA, USA) and Bax (monoclonal, Santa Cruz Biotechnology, Santa Cruz, CA, USA) at a dilution of $1: 1000$ in $5 \%$ (w/v) nonfat dry milk dissolved in PBS containing $0.05 \%(\mathrm{w} / \mathrm{v})$ Tween 20 (PBST). The primary antibodies were detected using the appropiate horseradish peroxidase-conjugated goat anti-mouse or horse anti-rabbit secondary antibodies (1:5000 dilution, Zymed Laboratories Inc., San Francisco, CA, USA). Protein was detected using a Bio-Rad Opti-4 CN substrate kit (Bio-Rad Laboratories, Hercules, CA, USA) or ECL-based detection (Pierce, Rockford, IL, USA) of chemiluminescence on film (Amersham Biosciences, Freiburg, Germany). Cultured neurons. Immunoblot analysis was performed as described previously. ${ }^{39}$ For each time point, the cells were harvested in lysis buffer containing $50 \mathrm{mM}$ Tris- $\mathrm{HCl}, 0.1 \%$ Triton $\mathrm{X}-100$, protease inhibitor cocktail (Complete Mini, Roche) and phosphatase inhibitor cocktails I and II (Sigma P5726, Sigma P2850). After homogenization and centrifugation at $14000 \times g$ for $15 \mathrm{~min}$ at $4^{\circ} \mathrm{C}$, protein concentrations were determined in the supernatant using the BCA kit (Perbio Science, Bonn, Germany). Equal amounts of total protein were loaded on $10 \%$ SDS-polyacrylamide gels. After separation by electrophoresis, the proteins were transferred onto a nitrocellulose membrane. Unspecific binding was blocked by a buffer containing $0.5 \%$ Tween- 20 and $5 \%$ nonfat dry milk in PBS. Later, the blots were incubated with primary antibodies diluted in $5 \%$ dry milk in PBS overnight at $4{ }^{\circ} \mathrm{C}$. Following antibodies were used: rabbit anti-XIAP (BD Biosciences, San Diego, CA, USA) and mouse anti-Bax (Santa Cruz Biotechnology, Santa Cruz, CA, USA). After washing the membranes with PBS, the blots were incubated with peroxidase-conjugated anti-mouse or anti-rabbit IgG $(1: 5000$, Vector Laboratories Inc.) at RT for $1 \mathrm{~h}$. After an additional wash with $0.05 \%$ Tween-20 in PBS, peroxidase activity was detected on X-ray film (CL-XPosure Film, Pierce) after incubation of the membrane with ECL solution (Amersham Biosciences).

Immunohistochemistry. Six hours after $\mathrm{CCl}$, brains of $\mathrm{C} 57 / \mathrm{B} 16$ mice were carefully removed and postfixed in $4 \%$ paraformaldehyde for $24 \mathrm{~h}$ at $4{ }^{\circ} \mathrm{C}$. Later, the brains were paraffin embedded, cut into $4 \mu \mathrm{m}$ sections and mounted on gelantinecoated slides. Sections were deparaffinized with rotihistol and rehydrated in a graded series of ethanol. For staining, a Histomouse-SP kit (Zymed Lab SA System, San Francisco, CA, USA) was used according to the manufacturer's instructions. Endogenous peroxidases were quenched with $3 \%$ hydrogen peroxide. After incubation with blocking reagents, slides were exposed to the p53-specific primary antibody (1C12 monoclonal, Cell Signaling Technologies, Beverly, MA, USA) at a dilution of $1: 50$ in PBS containing $0.3 \%$ Triton $X$ and $2 \%$ BSA. Sections were then incubated with a biotinylated secondary anti-mouse antibody and enzyme conjugate was added. Finally, the sections were incubated with the substrate chromogen mixture until staining became evident. The specificity of $p 53$ staining was confirmed by appropriate negative controls (no primary antibody). In order to determine nuclear versus cytosolic localization, p53-immunoreacted brain sections were counterstained with the fluorescent DNA-binding dye 4',6-diamidino-2-phenylindole dihydrochloride (DAPI) and analyzed with a confocal laser-scanning microscope (Zeiss, Jena, Germany).

Co-immunostainings. In order to verify nuclear translocation of $p 53$ and NF- $\kappa \mathrm{B}$ p65 and expression of XIAP in neurons, co-immunostainings were performed with the respective antibodies against anti-p53 (rabbit polyclonal, Santa Cruz Biotechnologies, Santa Cruz, CA, USA; $1: 100)$, anti-XIAP (1: 100), NF- $\kappa B$ p65 (rabbit polyclonal, NeoMarkers, Fremont, CA, USA; $1: 100$ ) and anti-NeuN (mouse monoclonal, 1:100; MAB377 Chemicon/Millipore, Billerica, MA, USA) antibodies. The antibodies were incubated on the brain slices in $4 \%$ goat serum ( $p 53, p 65$, XIAP) or $4 \%$ horse serum (NeuN) and detected with an anti-rabbit-biotinylated antibody/oregon green streptavidin system (Vector laboratories, Invitrogen) or antimouse-Alexa 546 antibody (Vector laboratories), respectively. Controls were processed either without any primary antibody or with only one of two primary antibodies used for co-labeling. Nuclei were counter-stained with DAPI. After the staining procedures, the sections were sealed under a coverslip with Fluorsave (Sigma) to prevent bleaching and then analyzed with a confocal laser-scanning microscope (DAPI: $364 \mathrm{~nm}$ excitation/385 nm longpass filter emission; Oregon green: 488/505-530 bandpass filter; Alexa 546: 543/560 longpass filter). All excitations were performed separately with fixed laser intensity settings to avoid unspecific signals and to compare staining intensities; further, cross signaling was excluded by measuring the respective negative controls and mono-stained sections with the same laser settings.

Electromobility shift assay. Tissue was homogenized (Potter S, B Braun Biotech) in $1 \mathrm{ml} \mathrm{Buffer} \mathrm{A} \mathrm{(10} \mathrm{mM} \mathrm{Hepes} \mathrm{pH} \mathrm{7.9;} 10 \mathrm{mM} \mathrm{KCl} ; 0.1 \mathrm{mM}$ EDTA; $0.1 \mathrm{mM}$ EGTA; $1 \mathrm{mM} \mathrm{DTT;} 0.5 \mathrm{mM}$ PMSF) and further incubated $\left(4^{\circ} \mathrm{C}, 20 \mathrm{~min}\right)$ in Buffer $A$ containing $25 \mu \mathrm{l} \mathrm{NP}-4010 \%$. Probes were centrifuged at 12500 r.p.m. for $1 \mathrm{~min}$, the supernatant was discarded and the remaining pellet was suspended in $50 \mu \mathrm{l} \mathrm{Buffer}$ B (20 mM Hepes pH 7.9; 0.4 mM NaCl; 1 mM EDTA; 1 mM EGTA; 20\% Glycerol; $1 \mathrm{mM} \mathrm{DTT} ; 0.1 \mathrm{mM}$ PMSF). Samples were kept at $4^{\circ} \mathrm{C}$ for 30 min under continuous shaking. After centrifugation at 12500 r.p.m. for $15 \mathrm{~min}$, supernatants were frozen at $-80^{\circ} \mathrm{C}$. Protein contents in the nuclear extracts were analyzed by the Bradford method. $^{38}$ The consensus binding sequence used for NF- $\kappa B$ was $5^{\prime}$ AGTTGAGGGGACTTTCCCAGGC-3' (Promega, Mannheim, Germany).

To ensure equal amounts of proteins, $25 \mu \mathrm{g}$ of protein were provided in a total amount of $14 \mu \mathrm{l}$, containing $2 \mu \mathrm{g}$ poly(dldC), $10 \mathrm{mM}$ Tris- $\mathrm{HCl}, 4 \%$ glycerol, $1 \mathrm{mM}$ $\mathrm{MgCl}_{2}, 0.5 \mathrm{mM}$ EDTA, $50 \mathrm{mM} \mathrm{NaCl}$ and $0.5 \mathrm{mM}$ DTT. Samples have been incubated for $10 \mathrm{~min}$ at RT. To start NF- $\kappa \mathrm{B}-\mathrm{DNA}$ binding reaction, $1 \mu \mathrm{l}$ of the radioactive-labeled oligonucleotide was added and samples were left for $30 \mathrm{~min}$ at RT. The protein-oligonucleotide complexes have been separated by gel electrophoresis (Mini-Protean 3, Bio-Rad) with $0.25 \times$ TBE buffer (containing $22.25 \mathrm{mM}$ Tris, $22.25 \mathrm{mM}$ boric acid and $0.5 \mathrm{mM}$ EDTA) at $100 \mathrm{~V}$ for $60 \mathrm{~min}$ using non-denaturizing polyacrylamide gels.

Following electrophoresis, gels have been exposed to cyclone storage phosphor screens (Canberra-Packard) for $24 \mathrm{~h}$, followed by analysis with a phosphor imager station (Cyclone Storage Phosphor System, Canberra-Packard).

Statistical analysis. Analysis was performed with the SigmaStat 2.0 software package (SPSS Inc., Richmond, CA, USA). Data are presented as means \pm S.D. or as indicated in the legends. Values were compared by Friedman's one-way analysis of variance ANOVA on ranks and Student-Newman-Keuls post hoc test. All values are given as means \pm S.D. if not indicated otherwise. For evaluation of cell culture experiments ANOVA combined with Scheffé's test was used for multiple comparisons. Statistical differences are presented at probability levels of $P<0.05, P<0.01$ and $P<0.001$.

Acknowledgements. We thank Melinda Kiss for excellent technical support. This work was supported by grants of the Deutsche Forschungsgemeinschaft (DFG) and Deutscher Akademischer Austauschdienst (DAAD) to CC and MR.

1. Raghupathi R. Cell death mechanisms following traumatic brain injury. Brain Pathol 2004; 14: $215-222$

2. Zweckberger K, Stoffel M, Baethmann A, Plesnila N. Effect of decompression craniotomy on increase of contusion volume and functional outcome after controlled cortical impact in mice. J Neurotrauma 2003; 20: 1307-1314.

3. Yuan J, Yankner BA. Apoptosis in the nervous system. Nature 2000; 407: 802-809.

4. Polster BM, Fiskum G. Mitochondrial mechanisms of neural cell apoptosis. J Neurochem 2004; 90: 1281-1289.

5. Culmsee C, Mattson MP. p53 in neuronal apoptosis. Biochem Biophys Res Commun 2005; 331: 761-777.

6. Cregan SP, MacLaurin JG, Craig CG, Robertson GS, Nicholson DW, Park DS et al. Baxdependent caspase-3 activation is a key determinant in p53-induced apoptosis in neurons. J Neurosci 1999; 19: 7860-7869.

7. Culmsee C, Zhu X, Yu QS, Chan SL, Camandola S, Guo Z et al. A synthetic inhibitor of $p 53$ protects neurons against death induced by ischemic and excitotoxic insults, and amyloid beta-peptide. J Neurochem 2001; 77: 220-228.

8. Crumrine RC, Thomas AL, Morgan PF. Attenuation of p53 expression protects against focal ischemic damage in transgenic mice. J Cereb Blood Flow Metab 1994; 14: 887-891.

9. Li Y, Chopp M, Zhang ZG, Zaloga C, Niewenhuis L, Gautam S. p53-immunoreactive protein and p53 mRNA expression after transient middle cerebral artery occlusion in rats. Stroke 1994; 25: 849-855.

10. Napieralski JA, Raghupathi R, Mclntosh TK. The tumor-suppressor gene, $p 53$, is induced in injured brain regions following experimental traumatic brain injury. Brain Res Mol Brain Res 1999; 71: 78-86.

11. Webster GA. Perkins ND. Transcriptional cross talk between NF-kappaB and p53. Mol Cell Biol 1999; 19: 3485-3495.

12. Culmsee C, Siewe J, Junker V, Retiounskaia M, Schwarz S, Camandola S et al. Reciprocal inhibition of $\mathrm{p} 53$ and nuclear factor-kappaB transcriptional activities determines cell survival or death in neurons. J Neurosci 2003; 23: 8586-8595.

13. Guegan C, Braudeau J, Couriaud C, Dietz GP, Lacombe P, Bahr M et al. PTD-XIAP protects against cerebral ischemia by anti-apoptotic and transcriptional regulatory mechanisms. Neurobiol Dis 2006; 22: 177-186.

14. Wang X, Zhu C, Wang X, Hagberg H, Korhonen L, Sandberg M et al. X-linked inhibitor of apoptosis (XIAP) protein protects against caspase activation and tissue loss after neonatal hypoxia-ischemia. Neurobiol Dis 2004; 16: 179-189.

15. Chopp M, Li Y. Transplantation of bone marrow stromal cells for treatment of central nervous system diseases. Adv Exp Med Biol 2006; 585: 49-64. 
16. Komarov PG, Komarova EA, Kondratov RV, Christov-Tselkov K, Coon JS, Chernov MV et al. A chemical inhibitor of p53 that protects mice from the side effects of cancer therapy. Science 1999; 285: 1733-1737.

17. Morrison RS, Kinoshita Y, Johnson MD, Guo W, Garden GA. p53-dependent cell death signaling in neurons. Neurochem Res 2003; 28: 15-27.

18. Leker RR, Aharonowiz M, Greig NH, Ovadia H. The role of p53-induced apoptosis in cerebral ischemia: effects of the p53 inhibitor pifithrin alpha. Exp Neurol 2004; 187: 478-486.

19. Tomita Y, Marchenko N, Erster S, Nemajerova A, Dehner A, Klein C et al. WT p53, but not tumor-derived mutants, bind to $\mathrm{Bcl} 2$ via the DNA binding domain and induce mitochondrial permeabilization. J Biol Chem 2006; 281: 8600-8606.

20. Chipuk JE, Green DR. Dissecting p53-dependent apoptosis. Cell Death Differ 2006; 13 994-1002.

21. Endo $\mathrm{H}$, Kamada $\mathrm{H}$, Nito $\mathrm{C}$, Nishi T, Chan PH. Mitochondrial translocation of p53 mediates release of cytochrome $\mathrm{C}$ and hippocampal $\mathrm{CA} 1$ neuronal death after transient global cerebral ischemia in rats. J Neurosci 2006; 26: 7974-7983.

22. Bhakar AL, Tannis LL, Zeindler C, Russo MP, Jobin C, Park DS et al. Constitutive nuclear factor-kappa B activity is required for central neuron survival. J Neurosci 2002; 22 : $8466-8475$.

23. Mattson MP. NF-kappaB in the survival and plasticity of neurons. Neurochem Res 2005; 30: 883-893.

24. Salminen A, Liu PK, Hsu CY. Alteration of transcription factor binding activities in the ischemic rat brain. Biochem Biophys Res Commun 1995; 212: 939-944.

25. Yang K, Mu XS, Hayes RL. Increased cortical nuclear factor-kappa B (NF-kappa B) DNA binding activity after traumatic brain injury in rats. Neurosci Lett 1995; 197: 101-104.

26. Zhang W, Potrovita I, Tarabin V, Herrmann O, Beer V, Weih F et al. Neuronal activation of NF-kappaB contributes to cell death in cerebral ischemia. J Cereb Blood Flow Metab 2005 25: $30-40$.

27. Schneider A, Martin-Villalba A, Weih F, Vogel J, Wirth T, Schwaninger M et al. NF-kappaB is activated and promotes cell death in focal cerebral ischemia. Nat Med 1999; 5: 554-559.

28. Deveraux QL, Schendel SL, Reed JC. Antiapoptotic proteins. The bcl-2 and inhibitor of apoptosis protein families. Cardiol Clin 2001; 19: 57-74.
29. Silke J, Ekert PG, Day CL, Hawkins CJ, Baca M, Chew J et al. Direct inhibition of caspase 3 is dispensable for the anti-apoptotic activity of XIAP. EMBO J 2001; 20: 3114-3123.

30. Silke J, Hawkins CJ, Ekert PG, Chew J, Day CL, Pakusch M et al. The anti-apoptotic activity of XIAP is retained upon mutation of both the caspase 3- and caspase 9-interacting sites. J Cell Biol 2002; 157: 115-124.

31. Siegelin M, Touzani O, Toutain J, Liston P, Rami A Induction and redistribution of XAF1, a new antagonist of XIAP in the rat brain after transient focal ischemia. Neurobiol Dis 2005; 20: $509-518$.

32. Trapp T, Korhonen L, Besselmann M, Martinez R, Mercer EA, Lindholm D. Transgenic mice overexpressing XIAP in neurons show better outcome after transient cerebral ischemia. Mol Cell Neurosci 2003; 23: 302-313.

33. Renwick J, Narang MA, Coupland SG, Xuan JY, Baker AN, Brousseau J et al. XIAPmediated neuroprotection in retinal ischemia. Gene Ther 2006; 13: 339-347.

34. Li T, Fan Y, Luo Y, Xiao B, Lu C. In vivo delivery of a XIAP (BIR3-RING) fusion protein containing the protein transduction domain protects against neuronal death induced by seizures. Exp Neurol 2006; 97: 301-308.

35. Voll RE, Jimi E, Phillips RJ, Barber DF, Rincon M, Hayday AC et al. NF-kappa B activation by the pre-T cell receptor serves as a selective survival signal in $T$ lymphocyte development. Immunity 2000; 13: 677-689.

36. Millet I, Phillips RJ, Sherwin RS, Ghosh S, Voll RE, Flavell RA et al. Inhibition of NF-kappaB activity and enhancement of apoptosis by the neuropeptide calcitonin gene-related peptide. J Biol Chem 2000; 275: 15114-15121.

37. Culmsee C, Zhu C, Landshamer S, Becattini B, Wagner E, Pellecchia M et al. Apoptosisinducing factor triggered by poly(ADP-ribose) polymerase and Bid mediates neuronal cell death after oxygen-glucose deprivation and focal cerebral ischemia. J Neurosci 2005; 25: 10262-10272.

38. Bradford MM. A rapid and sensitive method for the quantitation of microgram quantities of protein utilizing the principle of protein-dye binding. Anal Biochem 1976; 72: 248-254.

39. Culmsee C, Gerling N, Lehmann M, Nikolova-Karakashian M, Prehn JH, Mattson MP et al. Nerve growth factor survival signaling in cultured hippocampal neurons is mediated through TrkA and requires the common neurotrophin receptor P75. Neuroscience 2002; 115: $1089-1108$

\section{Supplementary Information accompanies the paper on Cell Death and Differentiation website (http://www.nature.com/cdd)}

